\title{
BLENDED PALM FRACTIONS AS CONFECTIONERY FATS: A PRELIMINARY STUDY
}

\section{NORAZURA AILA MOHD HASSIM*; SIVARUBY KANAGARATNAM* and NOOR LIDA HABI MAT DIAN*}

\begin{abstract}
The study looked into the mouldability of cocoa butter alternative (CBA) from blended palm fractions namely palm mid fraction (PMF) IV 45, palm kernel oil (PKO) and palm stearin (POs) IV 33 and IV 14 for the production of chocolate bar. PMF, PKO and POs IV 33 and IV 14 were blended in eight different optimised ratios based on solid fat content (SFC) response of more or close to $50 \%$ at $20^{\circ} \mathrm{C}$, SFC of less than $10 \%$ at $37^{\circ} \mathrm{C}$ and SFC of less than $5 \%$ at $40^{\circ} \mathrm{C}$ to produce a melt in the mouth and mouldable plain chocolate bar. Mouldability and snappability of the chocolate bar were the main parameters of the study. Physicochemical properties of the fat blends namely the fatty acid composition (FAC), triacylglycerol composition (TAG), solid fat content (SFC), crystallisation rate at isothermal temperature of $5^{\circ} \mathrm{C}, 10^{\circ} \mathrm{C}$ and $20^{\circ} \mathrm{C}$, thermal behaviour, polymorphism, crystal morphology and compatibility test with cocoa butter $(C B)$ for selected fat were also determined. Fat F blend with 91\% PMF, 1\% PKO, 5\% POs IV 33 and 3\% POs IV 14 showed the highest SFC $(47 \%)$ at $20^{\circ} \mathrm{C}$ and was able to be moulded and demoulded at $10^{\circ} \mathrm{C}$ by $45 \mathrm{~min}$. It has the highest rupture tension $\left(105.28 \mathrm{~g}_{f} \mathrm{~cm}^{-2}\right)$ and breaking force $\left(5501 \mathrm{~g}_{f}\right)$ at $10^{\circ} \mathrm{C}$. The composition of oleic acid, linoleic acid, total monounsaturated fatty acid, crystal morphology (density) as well as SFC profile at $20^{\circ} \mathrm{C}$ and crystallisation rate profile at $5^{\circ} \mathrm{C}, 10^{\circ} \mathrm{C}$ (after $40^{\text {th }} \mathrm{min}$ ) and $20^{\circ} \mathrm{C}$ (before $35^{\text {th }} \mathrm{min}$ ) of fat F were comparable with $\mathrm{CB}$ while other FAC, TAG, thermal behaviour and polymorphism were dissimilar to CB. Fat F, 10\%-30\% was observed to be compatible (no eutectic) with $C B$ and therefore, has the potential as fat for chocolate bar. The addition of $10 \%-30 \%$ of fat F to CB increased the SFC to $57 \%$ at $20^{\circ} \mathrm{C}$. Fat F $(30 \%)$ with CB could be demoulded by 30 min and produced snappability (breaking force) of $5032.71 \pm 85.91 \mathrm{~g}_{f}$ at $20^{\circ} \mathrm{C}$ after one day stabilisation period. Palm-based fat blend having 91\% PMF, 1\% PKO, 5\% POs IV 33 and 3\% POs IV 14 and CB has the potential to be used as alternative fat for chocolate bar which can eventually benefit the confectionery industry.
\end{abstract}

Keywords: blended palm fractions, chocolate bar, confectionery fats, mouldability, rupture tension.

Received: 4 June 2020; Accepted: 17 August 2020; Published online: 17 November 2020.

\section{INTRODUCTION}

Fat is an important ingredient for chocolate and other confectionery products as it has a major influence on their organoleptic and physical

\footnotetext{
Malaysian Palm Oil Board,

6 Persiaran Institusi, Bandar Baru Bangi,

43000 Kajang, Selangor, Malaysia.

E-mail: azuraaila@mpob.gov.my
}

properties. It is responsible for the snap, appearance, mouthfeel and flavour release of chocolate confectionery (Rios et al., 2014). Cocoa butter (CB) is the traditional fat for chocolate confectionery. It contains three main fatty acids which are palmitic, stearic and oleic. The primary triacylglycerols (TAG) composition of $\mathrm{CB}$ are the 1,3-dipalmitoyl-2-oleoyl glycerol (POP), 1(3)-stearoyl-2-oleoyl-3(1)-palmitoyl glycerol (POS) and disaturated 1,3-distearoyl-2- 
oleoyl glycerol (SOS) (Mohamed, 2013). This TAG composition is responsible for the sharp melting of $\mathrm{CB}$ between $30^{\circ} \mathrm{C}$ and $35^{\circ} \mathrm{C}$ but maintains a solid consistency at $20^{\circ} \mathrm{C}$ which is desirable for chocolate confectionery (Timms, 2003). Due to difficulty in cultivation of cocoa plants, low productivity and pest attacks, the production of $\mathrm{CB}$ is hampered although its demand is high. These scenarios lead to the production of $\mathrm{CB}$ alternatives (CBA) and are classified into three groups namely $\mathrm{CB}$ equivalent (CBE) having similar physicochemical properties as $C B$, non-lauric $C B$ replacer $(C B R)$ and lauricbased CB substitutes (CBS) having similar physical properties but different chemical properties from $\mathrm{CB}$ (Norazura Aila and Noor Lida, 2017).

There are various methods in producing confectionery fats which include blending, fractionation, hydrogenation and interesterification. Based on various studies, currently, interesterification, supercritical extraction and enhanced fractionation are the focus of CBA research. Palm mid fraction (PMF) has been the focus for interesterification studies, particularly enzymatic, for the production of CBE and has been discussed in many published articles ( $\mathrm{Wu}$ and Deng, 2005; Borhan et al., 2011; Soekopitojo et al., 2009; Soekopitojo, 2011; Gibon, 2011; Mohamed, 2013; Mutia et al., 2016; Biswas et al., 2018). Supercritical carbon dioxide process has been employed by Nik Norulaini et al. (2004) and Zaidul et al. (2006; 2007) to further process palm kernel oil (PKO) to obtain CBE and CBR, respectively. Timms (2003) reported that the simplest CBS was produced through hydrogenation of PKO. Calliauw et al. (2005) published article describing the process of obtaining high-quality CBS from PKO through a two-stage static fractionation process. Kang et al. (2003; 2013) demonstrated the production of $\mathrm{CBE}$ with palm stearin (POs) through additional acetone fractionation process. However, interesterification, supercritical extraction, hydrogenation and enhanced fractionation are highly processed methods. We are of the opinion that blending on the other hand is simple and straight forward compared to the above processes.

PMF (IV 45) that is obtained through second stage dry fractionation of palm oil (De Clercq et al., 2012) exhibiting melting points between those of POs and palm olein (POo) (Sakamotoa et al., 2004) has been vastly utilised for blending with other vegetable fats in the production of $\mathrm{CBE}$. These vegetable fats include exotic fats (Talbot, 2009; Elham et al., 2013; Jun et al., 2016) as well as hard stearin and high oleic-high stearic sunflower hard stearins (Bootello et al., 2012; 2013). Having high level of POP makes PMF the fat of choice for blending with other sources of fats containing high POS and SOS TAG composition to mimic TAG composition of CB
(Sonwai et al., 2014). In addition, PMF offers unique melting profile similar to $\mathrm{CB}$. To-date, no study has been found for blending of PKO with other fats for the hard-confectionery application. However, blend of PKO with other fats is found to be suitable for confectionery filling by Biswas et al. (2017). As PKO (lauric fat) is rich in lauric and myristic fatty acids, eutectic might be a challenge when it is blended with non-lauric fats. POs has been used extensively as natural alternative to eliminate transfat especially in formulating hardstock such as margarine and shortening. Few blending studies of POs and other fats for confectionery application have been investigated earlier. These include studies by Jahurul et al. (2014b) that blended POs and mango seed fat as a CBR and Cain et al. (1995) that blended PKO and palm kernel stearin (PKS) for hard coating application.

Hard PMF having IV 35 has been acknowledged to be useful for hard-confectionery (BraipsonDanthine and Gibon, 2007). However, blended soft PMF (IV 45) with other palm fractions has yet to be proven for hard-confectionery applications. Therefore, in this study, blended PMF IV 45, POs (IV 33 and/or IV 14) and PKO at optimised ratios based on solid fat content (SFC) were investigated in term of physicochemical properties including their mouldability for the hard-confectionery application. POs might be able to increase SFC of the blended fats and enhance crystallisation rate while PKO could minimise tailing of the blended fats.

\section{MATERIALS AND METHODS}

\section{Materials}

PMF IV 45 and refined, bleached and deodourised (RBD) PKO were obtained from Cargill Palm Product Sdn. Bhd., Malaysia while RBD POs IV 33 was obtained from Sawit Raya Sdn. Bhd., Malaysia. RBD POs IV 14 was provided by Mewah Oils Sdn. Bhd., Malaysia. In this article, RBD PKO, RBD POs IV33 and RBD POs IV14 were simplified as PKO, POs IV33 and POs IV14, respectively.

\section{Experimental Design and Preparation of Fat}

Interaction of blended fats namely PMF / PKO/ POs IV 33/ POs IV 14 were studied using simplexlattice design. SFC was used as the response parameter. Twenty randomised trials including five replicates were used as inputs before optimisation. Experimental error and fit of the model was determined from the replications. Scheffe model was used to fit a polynomial equation. Analysis of variance (ANOVA) was used to check quality of the model. Optimisation of the blended fats was conducted based on SFC parameter. Targeted SFC 
values were more than $45 \% \mathrm{SFC}$ at $20^{\circ} \mathrm{C}$, less than $10 \% \mathrm{SFC}$ at $37^{\circ} \mathrm{C}$, and less than $5 \% \mathrm{SFC}$ at $40^{\circ} \mathrm{C}$. These were carried out using point prediction method.

The PMF, PKO, POs IV 33 and POs IV 14 were then mixed at different ratios as shown in Table 1 according to the optimised ternary diagram when POs IV 14 was set to zero and optimised ternary diagram when POs IV 14 was set to $2 \%$ and $3 \%$. The fats were melted at $80^{\circ} \mathrm{C}$ for at least $1 \mathrm{hr}$ prior to mixing.

TABLE 1. FAT BLENDS OF PMF/PKO/POs IV 33/POs IV 14 PRODUCED THROUGH MIXTURE DESIGN

\begin{tabular}{ccccc}
\hline $\begin{array}{c}\text { Fat } \\
\text { blend }\end{array}$ & $\begin{array}{c}\text { PMF } \\
\mathbf{( \% )}\end{array}$ & $\begin{array}{c}\text { PKO } \\
(\boldsymbol{\%})\end{array}$ & $\begin{array}{c}\text { POs IV 33 } \\
\mathbf{( \% )}\end{array}$ & $\begin{array}{c}\text { POs IV 14 } \\
\mathbf{( \% )}\end{array}$ \\
\hline A & 88 & 1 & 11 & 0 \\
B & 89 & 1 & 10 & 0 \\
C & 91 & 1 & 8 & 0 \\
D & 92 & 1 & 7 & 0 \\
E & 96 & 1 & 3 & 0 \\
F & 91 & 1 & 5 & 3 \\
G & 93 & 1 & 3 & 3 \\
H & 95 & 1 & 2 & 2 \\
\hline
\end{tabular}

Note: PMF - palm mid fraction; PKO - palm kernel oil; POs - palm stearin.

\section{Solid Fat Content}

SFC of the blended fats was measured according to American Oil Chemists' Society (AOCS) Official Method Cd 16b-93 (AOCS, 2012) using pulsed nuclear magnetic resonance (NMS Minispec from Bruker, Germany). Samples were melted at $80^{\circ} \mathrm{C}$ for $1 \mathrm{hr}$ and filled into NMR tubes of $0.8 \mathrm{~cm}$ (diameter) and $3 \mathrm{~cm}$ (height). For this procedure, samples were chilled for $90 \mathrm{~min}$ at $0^{\circ} \mathrm{C}$, followed by tempering for $40 \mathrm{hr}$ at $26^{\circ} \mathrm{C}, 90 \mathrm{~min}$ at $0^{\circ} \mathrm{C}$ and finally maintained for $60 \mathrm{~min}$ at desired test temperatures of $5^{\circ} \mathrm{C}, 10^{\circ} \mathrm{C}$, $15^{\circ} \mathrm{C}, 20^{\circ} \mathrm{C}, 25^{\circ} \mathrm{C}, 30^{\circ} \mathrm{C}, 35^{\circ} \mathrm{C}, 37^{\circ} \mathrm{C}$ and $40^{\circ} \mathrm{C}$ prior to each measurement.

\section{Fatty Acid Composition (FAC)}

FAC of the blended fat was analysed using gas chromatography (GC) based on fatty acid methyl esters (FAME) according to MPOB Test Methods p3.5 (MPOB, 2005). Samples of $0.1 \mathrm{~g}$ were weighed and dissolved in $1.8 \mathrm{ml}$ hexane. The sample's solution was then mixed with a vortex mixer. Sodium methoxide solution $(100 \mu \mathrm{l})$ was added to the samples for methylation process followed by water addition. Mixing was performed in between each process. The sample's solution was left for $1 \mathrm{hr}$ to separate. The clear supernatant was transferred to another vial added with sodium sulphate anhydrous and kept for 15 min before complete clear supernatant $(1.5 \mathrm{ml})$ was injected into GC (Agilent Technologies, Model 7890B). The GC was equipped with a flame ionisation detector (FID).
The injector and detector temperatures were both set at $240^{\circ} \mathrm{C}$ while the column temperature was set at $185^{\circ} \mathrm{C}$. Helium gas (carrier) with flow rate of $1 \mathrm{ml} \mathrm{min}{ }^{-1}$ was used. The peaks were identified by comparing retention times with FAME standards and quantified using peak area normalisation method.

\section{Triacylglycerol Composition (TAG)}

TAG composition was performed using ultra high-performance liquid chromatography (U-HPLC) system (1290 Infinity LC System, Agilent Technologies, USA) and Agilent 1260 RI detector (Waters Corp., USA) according to AOCS Official Method Ce 5b-89 (AOCS, 2012). A Cortecs UPLC C18 column (2.1 mm x $150 \mathrm{~mm}$ length i.d; $1.6 \mu \mathrm{m}$ particle size) (Waters Corp., Milford, Massachusettes, USA) maintained at $30^{\circ} \mathrm{C}$ was used. The mobile phased used was a mixture of acetone-acetonitrile with the ratio of $63.5: 36.5(\mathrm{v} / \mathrm{v})$ at a flow rate of $0.25 \mathrm{ml} \mathrm{min}^{-1}$. Samples $(0.1 \mathrm{~g})$ was solubilised in $1 \mathrm{ml}$ of acetone. The chemicals and reagents used were HPLC grade. HPLC analysis was conducted in duplicate and data was recorded as percent areas.

\section{Crystallisation Rate at Isothermal Temperature}

Crystallisation rate was measured using pulsed nuclear magnetic resonance (NMS Minispec from Bruker, Germany) according to Chen et al. (2015) with modification. Samples were melted at $80^{\circ} \mathrm{C}$ for $1 \mathrm{hr}$. NMR tubes of $0.8 \mathrm{~cm}$ (diameter) and 3 $\mathrm{cm}$ (height) were used in this analysis. Tubes with samples were held for $1 \mathrm{hr}$ at $30^{\circ} \mathrm{C}$. The tubes were then placed at $5^{\circ} \mathrm{C}, 10^{\circ} \mathrm{C}$ and $20^{\circ} \mathrm{C}$. SFC readings were taken every 1-5 $\mathrm{min}$.

\section{Thermal Behaviour}

Thermal properties of the oil samples were measured using a differential scanning calorimetry (DSC)-7 (Perkin Elmer, Norwalk, CT). Calibration was performed using an indium standard and n-decane. Oil sample of 3-5 mg was hermetically sealed in an aluminium pan. The following temperature programme was used to perform the melting and cooling measurements on each sample: cooled to $-40^{\circ} \mathrm{C}$ at $5^{\circ} \mathrm{C} \mathrm{min}^{-1}$, held at $-40^{\circ} \mathrm{C}$ for 5 min and then heated to $80^{\circ} \mathrm{C}$ at $5^{\circ} \mathrm{C} \mathrm{min}^{-1}$ following temperature programme from Biswas et al. (2017) with modification.

\section{Polymorphism}

Polymorphism was determined at room temperature using coupled X-ray Diffraction (XRD)-DSC Rigaku TTRAX III (Tokyo, Japan). 
The sample holders were flat stainless-steel plates with rectangular holes. The X-ray incident-beam $2 \theta$ range was from $1^{\circ}-30^{\circ}$ with scanning rate of $5^{\circ} \mathrm{C}$ min $^{-1}$ according to Biswas et al. (2017) with modification. Samples were melted at $80^{\circ} \mathrm{C}$ and tempered at $10^{\circ} \mathrm{C}$ for 30,45 and $60 \mathrm{~min} . \alpha, \beta^{\prime}$ and $\beta$ polymorphs were determined using short spacing characterisations.

\section{Crystal Morphology}

Crystal microstructure of the fats were determined using Polarised Light Microscope (PLM) following the method as described by Narine and Marangoni (1999). A small droplet (about $15 \mu \mathrm{l}$ ) of melted fat was placed on a glass slide and covered with a glass slip. The sample was first heated to $80^{\circ} \mathrm{C}$ for $20 \mathrm{~min}$ to erase crystal memory. The sample was tempered at $10^{\circ} \mathrm{C}, 20^{\circ} \mathrm{C}$ and $25^{\circ} \mathrm{C}$ for 48 hr prior to measurement. A Leica DMLP polarised light microscope (Wetzlar, Germany) equipped with a Linkam THMS 600 temperature controller stage and a JVC 3-CCD colour video camera was used. Temperature was thermostatically controlled by a Linkam TP 94 multiramp temperature programme conching machine and LNP automatic cooling system (Linkam, Tadworth, Surrey, United Kingdom). Liquid nitrogen was used as the coolant. The photomicrograph of the crystal was taken at 50X magnification.

\section{Mouldability}

Chocolate bars were produced from the blended fats according to plain chocolate formulation by Timms (2003) as per Table 2. The amount of cocoa powder, sugar, blended fat and lecithin were made constant in order to produce the chocolate bars. These raw materials were then refined using 3-mill refiner and conched using chocolate conching machine. The chocolate bars were cooled at $10^{\circ} \mathrm{C}$ (Keijbets et al., 2010) for 30, 45 and $60 \mathrm{~min}$. The bars were not subjected to further solidification period. Mouldability of the chocolate bars were determined based on observation of the moulding and demoulding activity (easy demoulding or otherwise). Triplicates of chocolate bars were produced for each blended fat.

TABLE 2. FORMULATION OF PLAIN CHOCOLATE

\begin{tabular}{lcc}
\hline Ingredients & $\begin{array}{c}\text { Weight } \\
(\mathbf{\%})\end{array}$ & $\begin{array}{c}\text { Weight } \\
(\mathbf{g})\end{array}$ \\
\hline Cocoa powder & 20.00 & 200.00 \\
Blended fat & 33.00 & 330.00 \\
Sugar & 46.60 & 466.00 \\
Lecithin & 0.40 & 4.00 \\
\hline Total & 100.00 & 1000.00 \\
\hline
\end{tabular}

Source: Timms (2003).

\section{Mechanical Resistance Test (Snappability)}

Snappability of the chocolate bars at $10^{\circ} \mathrm{C}$ was conducted using a Texture Analyser (TA-XTplus, Stable Micro Systems) with a Three Bend Rig probe according to Stroppa et al. (2014) and Jorge et al. (1999). The setting for pre-test velocity was $3 \mathrm{~mm} \mathrm{~s}^{-1}$, test velocity was $1.7 \mathrm{~mm} \mathrm{~s}^{-1}$ and post-test velocity of $10 \mathrm{~mm} \mathrm{~s}^{-1}$. Rupture force was adjusted to the center of the chocolate bars. Three repetitions were conducted for each chocolate having different fat blends and CB. The values of the force obtained were divided by the cross-section area of each bar and the unit for the rupture tension was reported in $\mathrm{g}_{\mathrm{f}} \mathrm{cm}^{-2}$ in order to eliminate the effect of thickness variations of the bars.

\section{Compatibility Test}

The results obtained from our preliminary analysis were utilised to select the best blended palm fractions. The selected fat was blended with $\mathrm{CB}$ at different ratio $(0 \%-100 \%)$. The SFC at $20^{\circ} \mathrm{C}$ for all ratios were determined according to AOCS Official Method Cd 16b-93 (AOCS, 2012). Mouldability at $10^{\circ} \mathrm{C}$ and mechanical resistance test at $20^{\circ} \mathrm{C}$ were conducted for blend of selected fats and $\mathrm{CB}$.

\section{Statistical Analysis}

Results were analysed with Minitab version 16.0 (Pennsylvania, USA) using one-way ANOVA. Significance differences $(\mathrm{p} \leq 0.05)$ among the samples were analysed using the Tukey's post-hoc test. All tests were carried out in duplicate or triplicate.

\section{RESULTS AND DISCUSSION}

\section{Solid Fat Content}

SFC profiles of the fats are shown in Figure 1. CB had a high SFC at low temperature, the SFC then decreased sharply from $20^{\circ} \mathrm{C}-35^{\circ} \mathrm{C}$ with $0 \% \mathrm{SFC}$ at $35^{\circ} \mathrm{C}$. Similar finding was reported by Biswas et al. (2017) and Kadivar et al. (2016) in which some finding showed $0 \% \mathrm{SFC}$ at $37^{\circ} \mathrm{C}$ based on its varieties. The sharp melting profile is due to its significant level of SOS and POS TAG (Biswas et al., 2017; Kadivar et al., 2016). All of the eight blended fats PMF/PKO/POs (IV 33 and/or IV 14) showed marginal difference in SFC profiles at all temperatures tested. This was explained by the minor deviation in TAG value of all the fats (Table 4). This trend was also reported by Jahurul et al. (2014a) when blending PMF with mango seed fat to produce CBE. Blended PMF / PKO/POs (IV 33 and/or IV 14) had $76 \%-79 \%$ SFC at $5^{\circ} \mathrm{C}$. 
A steep decrease of SFC in all the fats occurred between $15^{\circ} \mathrm{C}-25^{\circ} \mathrm{C}$ with zero solid at $40^{\circ} \mathrm{C}$. Fat $\mathrm{F}$ had the highest SFC at $20^{\circ} \mathrm{C}$ having value of $47 \%$ followed by fats $G$ and $H$. Higher percentage of trisaturated TAG led to higher SFC (Zhou et al., 2010). Overall, all of the blended fats (PMF/PKO/ POs (IV 33 and/or IV 14)) exhibited similar SFC trend as compared to $\mathrm{CB}$ with high $\mathrm{SFC}$ at low temperature, nearly zero $\mathrm{SFC}$ at $35^{\circ} \mathrm{C}-40^{\circ} \mathrm{C}$ and high melting profile in between. Hence, these blended fats have the potential to be used as confectionery fat.

\section{Fatty Acid Composition}

FAC of the eight blended fats are tabulated in Table 3. The main fatty acids in $\mathrm{CB}$ are palmitic acid (C16:0), stearic acid (C18:0) and oleic acid (C18:1). This has been described in numerous earlier studies, among others were by Żyżelewics et al. (2014), Jahurul et al. (2013) and Compos and Marangoni (2010). Fatty acid profile of the eight blended fats was more diverse with major fatty acids being palmitic and oleic acids, followed by linoleic acid (C18:2). Other fatty acids were present in small quantity in the fats. Lauric acid (C12:0) and myristic acid (C14:0) values in all blended fats were low $(0.70 \%-1.10 \%$ and $1.41 \%-1.89 \%$, respectively) as only $1 \%$ PKO was recommended after optimisation. Palmitic acid in all fats was significantly different $(p<0.05)$ and observed to be higher than in CB. Stearic acid in all the blended fats $(A-H)$ was not significantly different $(p>0.05)$. It was observed that stearic acid in all fats was significantly lower than in CB. Although the values of oleic acid for all the blended fats were found to be close to one another and in $\mathrm{CB}$, composition of oleic acid in all the fats was examined to be significantly different $(p<0.05)$ compared to each other and CB. Polyunsaturated fatty acid (PUFA) of all blended fats $(\mathrm{A}-\mathrm{H})$ was observed to be higher than in CB. The trait of unsaturated fatty acids was that it has lower melting points due to the existence of double bonds (Larsen et al., 2014). In this study, the amounts of oleic and linoleic as well as monounsaturated (MUFA) fatty acids (palmitoleic acid and oleic acid) were comparable to $\mathrm{CB}$.

\section{Triacylglycerol Composition}

The TAG composition of all fats is shown in Table 4. TAG (18 types) were found in CB. Saturatedunsaturated-saturated (SUS) TAG namely POS, SOS and POP dominated TAG of CB having $39.26 \%$, $31.11 \%$ and $16.18 \%$, respectively. Both PMF and POs were hard fractions of dry fractionation. TAG (16 types) were identified in all fat blends. Major TAG in all fat blends were POP, followed by PLP.

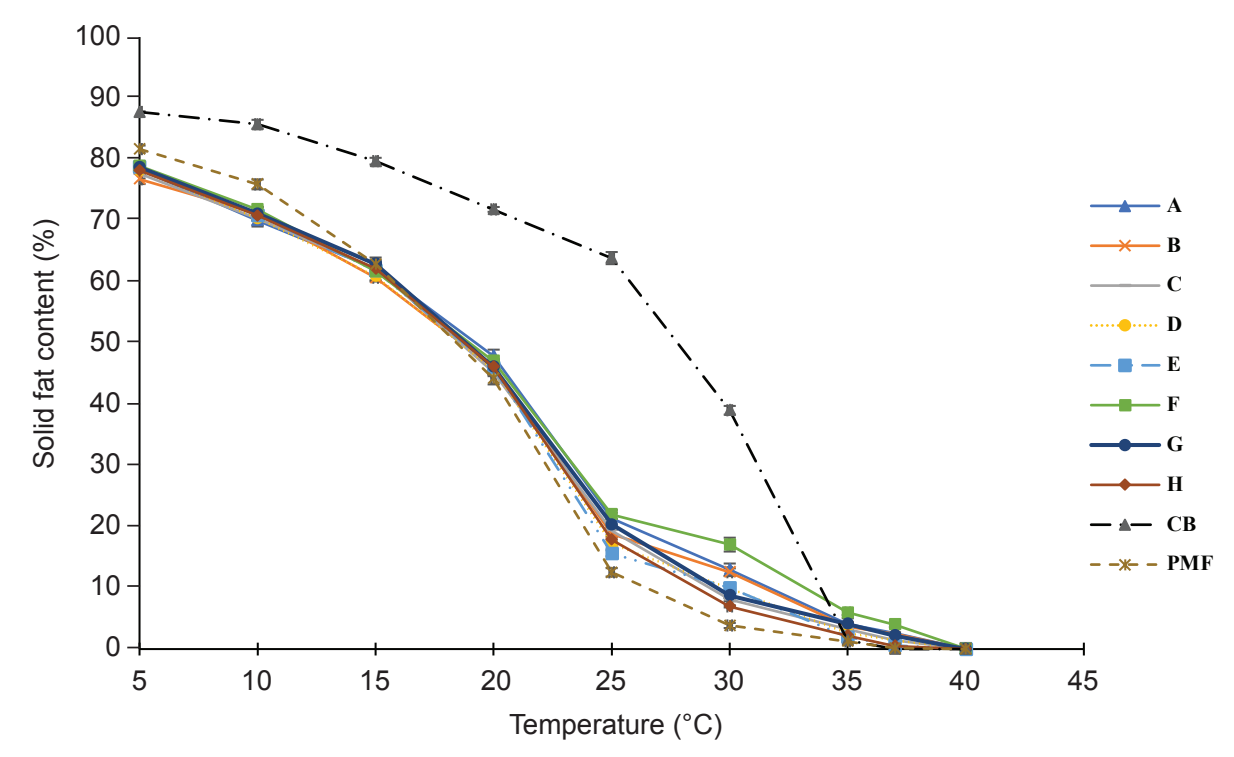

Note: Fat A - 88\% PMF, 1\% PKO, 11\% POs IV 33.

Fat B - 89\% PMF, 1\% PKO, 10\% POs IV 33.

Fat C - 91\% PMF, 1\% PKO, 8\% POs IV 33.

Fat D-92\% PMF, 1\% PKO, 7\% POs IV 33.

Fat E - 96\% PMF, 1\% PKO, 3\% POs IV 33.

Fat F-91\% PMF, 1\% PKO, 5\% POs IV 33 and 3\% POs IV 14.

Fat G- 93\% PMF, 1\% PKO, 3\% POs IV 33 and 3\% POs IV 14.

Fat $\mathrm{H}-95 \%$ PMF, 1\% PKO, 2\% POs IV 33 and 2\% POs IV 14.

$\mathrm{CB}$ - cocoa butter; PMF - palm mid fraction; PKO - palm kernel oil; POs - palm stearin.

Figure 1. Solid fat content of blended fats, cocoa butter and palm mid fraction. 
High content of POP TAG is responsible for the $\beta^{\prime}$ crystal formation (Toro-Vazquez et al., 2004). As percentage of PKO was very minor in all fats, LLL, LLM and LMM TAG were not present/detected. The values of POP TAG among the blended fats were comparable to each other having values ranging from $48.52 \%-50.28 \%$. However, the POP TAG of these blends was significantly different $(p<0.05)$ from CB. The POS and SOS TAG of the blended fats did not differ much from one another having the range of $9.16 \%-9.58 \%$ and $1.08 \%-1.38 \%$, respectively. However, both of the TAG were significantly different with $C B(p<0.05)$. All of the blended fats had higher unsaturated-unsaturatedunsaturated (UUU) TAG $(1.12 \%-1.34 \%)$ compared to $\mathrm{CB}(0.17 \%)$. Saturated-unsaturated-unsaturated (SUU) TAG of the blended fats was higher than CB ranging from $14.52 \%-15.42 \%$. Despite of this, SUS TAG for all blended fats was found to be higher in $\mathrm{CB}(88.79 \%)$ compared to the blended fats (59.07\%-60.84\%). Saturated-saturated-saturated (SSS) TAG of the blended fats ranged from $17.06 \%$ $18.97 \%$ while similar TAG in CB showed a value of $5.51 \%$. Fat F exhibited the highest SSS TAG of $18.45 \%$ among all the blended fats. Majority of the fats contained insignificant TAG $(p>0.05)$ which included PLL, OLO, OOO, POO, SOO, POS and SOS.

In the present study, the most significantly different $(p<0.05)$ TAG was PPP. PPP increased progressively with the addition of POs (POs IV 33 and POs IV 14). The addition of POs to PMF improved the SFC due to the presence of high melting fraction (Jahurul et al., 2014a) such as PPP. Further addition of POs IV 14 increased the level of PPP significantly $(\mathrm{p}<0.05)$. However, PPP is an undesirable TAG as it provides waxiness to the end product (Cleenewerck, 2010). The use of POs IV 14 in the formulation was low in percentage for fats $\mathrm{F}$, $\mathrm{G}$ and $\mathrm{H}$ with values of 3\%, 3\% and 2\%, respectively. However, fats F, G and $\mathrm{H}$ also consisted of 5\%, 3\% and 2\% of POs IV 33, respectively. The value of PPP for fats F, G and $\mathrm{H}$ increased tremendously compared to fats A-E that have no POs IV 14 in the formulation and only comprised of POs IV 33 of $11 \%, 10 \%, 8 \%, 7 \%$ and $3 \%$, respectively. There is potential of using single POs namely POs IV 14 as substitute to POs IV 33 if PPP could be of an assistance for the chocolate mouldability. All of the TAG of the blended fats were not comparable to CB. However, the increased level of PPP in the formulation facilitates crystallisation (Basso et al., 2010) and eventually the mouldability property.

\section{Crystallisation Rate at Isothermal Temperature}

Crystallisation rates of all the fats at $5^{\circ} \mathrm{C}, 10^{\circ} \mathrm{C}$ and $20^{\circ} \mathrm{C}$ (isothermal temperature) are shown in Figure 2. At $5^{\circ} \mathrm{C}, \mathrm{CB}$ reached $80 \%$ SFC within $10 \mathrm{~min}$ and began to plateau at $90 \%$ SFC by $20^{\text {th }}$ min. The eight fat blends, on the other hand, did not reach $50 \%$ SFC at $10^{\text {th }}$ min crystallisation time. The SFC of all fat blends at $5^{\circ} \mathrm{C}$ were close to each other. Overlapping of SFC of all fats started to be observed by $35^{\text {th }}-40^{\text {th }}$ min of crystallisation time. PMF followed by fat E illustrated the slowest crystallisation rate at $5^{\circ} \mathrm{C}$. At $10^{\circ} \mathrm{C}, \mathrm{CB}$ reached $80 \%$ SFC by the $15^{\text {th }}-20^{\text {th }}$ min crystallisation time. By the $30^{\text {th }}-35^{\text {th }}$ min, the SFC of CB begun to plateau. Fats A, B, C, D, F, G and $\mathrm{H}$ demonstrated overlapping SFC by the $40^{\text {th }}-45^{\text {th }}$ min of crystallisation rate. POs which was part of the formulation played important role in this crystallisation pattern. PPP which is the highest melting fraction in POs influenced the fat crystallisation (Basso et al., 2010; Vereecken et al., 2009) as agent for seeding and crystallisation booster particularly for POP-containing system (Vereecken et al., 2009). PMF and fat E still exhibited the lowest crystallisation rate at $10^{\circ} \mathrm{C}$.

At $10^{\text {th }}$ min, CB had the highest SFC compared to other fats at isothermal temperature of $20^{\circ} \mathrm{C}$. Fat $\mathrm{F}$ showed the highest crystallisation rate from $1^{\text {st }}-20^{\text {th }}$ min compared to CB. Fats A, B, C, F, G and $\mathrm{H}$ demonstrated higher crystallisation rate than CB from $25^{\text {th }}-35^{\text {th }} \mathrm{min}$. At $40^{\text {th }} \mathrm{min}$ and above, $\mathrm{CB}$ had the highest SFC at $20^{\circ} \mathrm{C}$ imposing fastest crystallisation compared to other fats. Foubert et al. (2006) suggested that the shift of slope in $\mathrm{CB}$ may be due to the development of distinct polymorphic form or occurrence of various fractions crystallisation. Unblended PMF fat showed the poorest crystallisation performance at this isothermal temperature with only very minor increase of SFC towards $60^{\text {th }} \mathrm{min}$. Similar result was obtained by Peyronel et al. (2016) when rapid crystallisation of PMF started to take place only after 1.5 hr. POP and PPP played important role in determining the rate of crystallisation at isothermal condition of $20^{\circ} \mathrm{C}$ of all the fats. Higher content of POP in PMF made the crystallisation rate slower. Fat E, having the highest POP content and lowest PPP content, resulted to the lowest crystallisation rate among all of the fats. This result was aligned with the study by Sonwai et al. (2014) who reported higher crystallisation rate of PMF when the POP level was low.

In the present study, crystallisation rate of all blended fats was found to have less effect at low temperature of $5^{\circ} \mathrm{C}$. All of the blends have close crystallisation rate profile with $\mathrm{CB}$. However, at $10^{\circ} \mathrm{C}$ and $20^{\circ} \mathrm{C}$, crystallisation rate of all the blended fats varied from other another as well as with $C B$. At $10^{\circ} \mathrm{C}$, the crystallisation rate of all the fat blends had similar plateau profile as $C B$ after $40^{\text {th }} \mathrm{min}$. Notwithstanding this, similar crystallisation rate profile was found for all of the fat blends with $\mathrm{CB}$ before $35^{\text {th }} \mathrm{min}$ at $20^{\circ} \mathrm{C}$. 


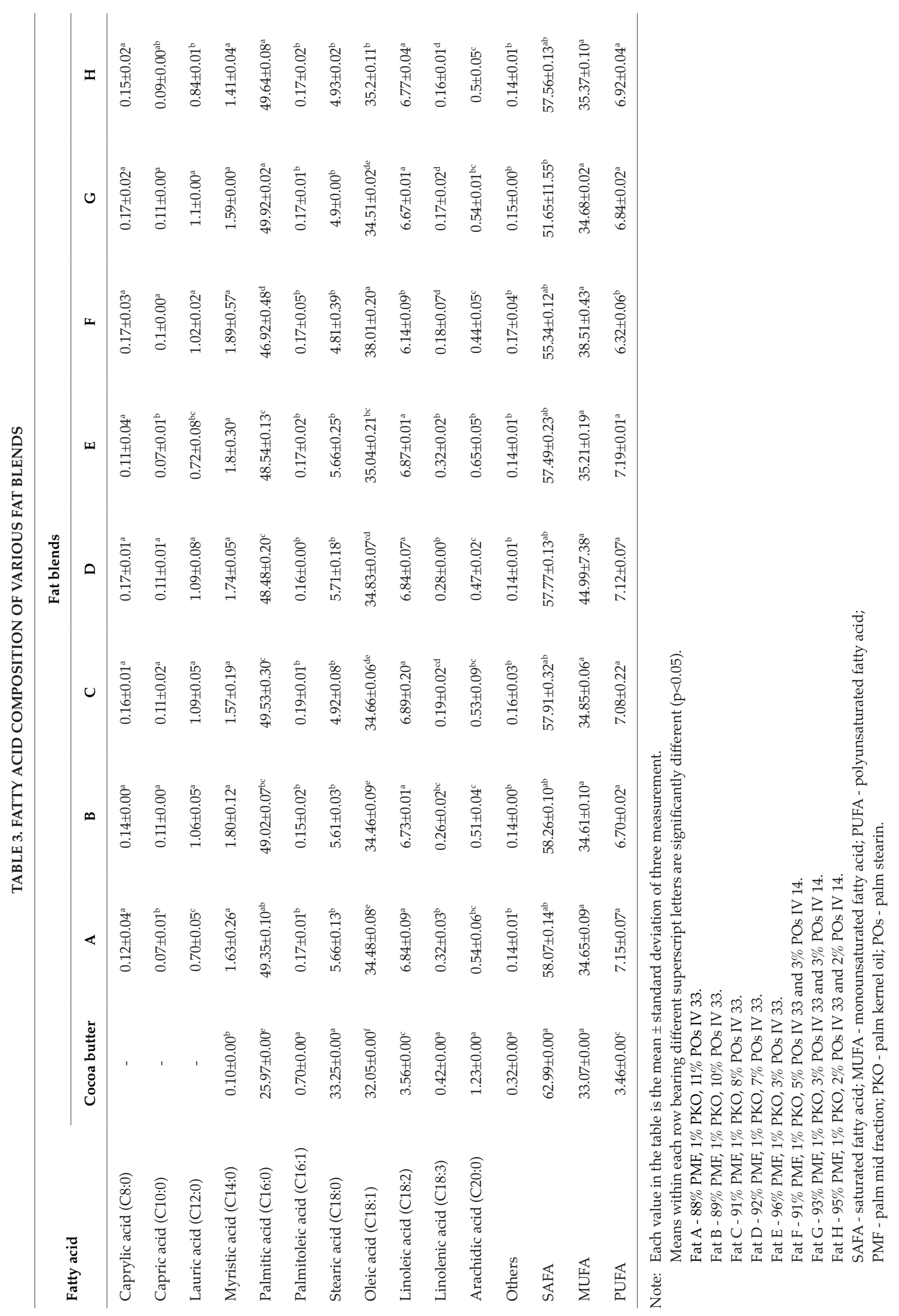




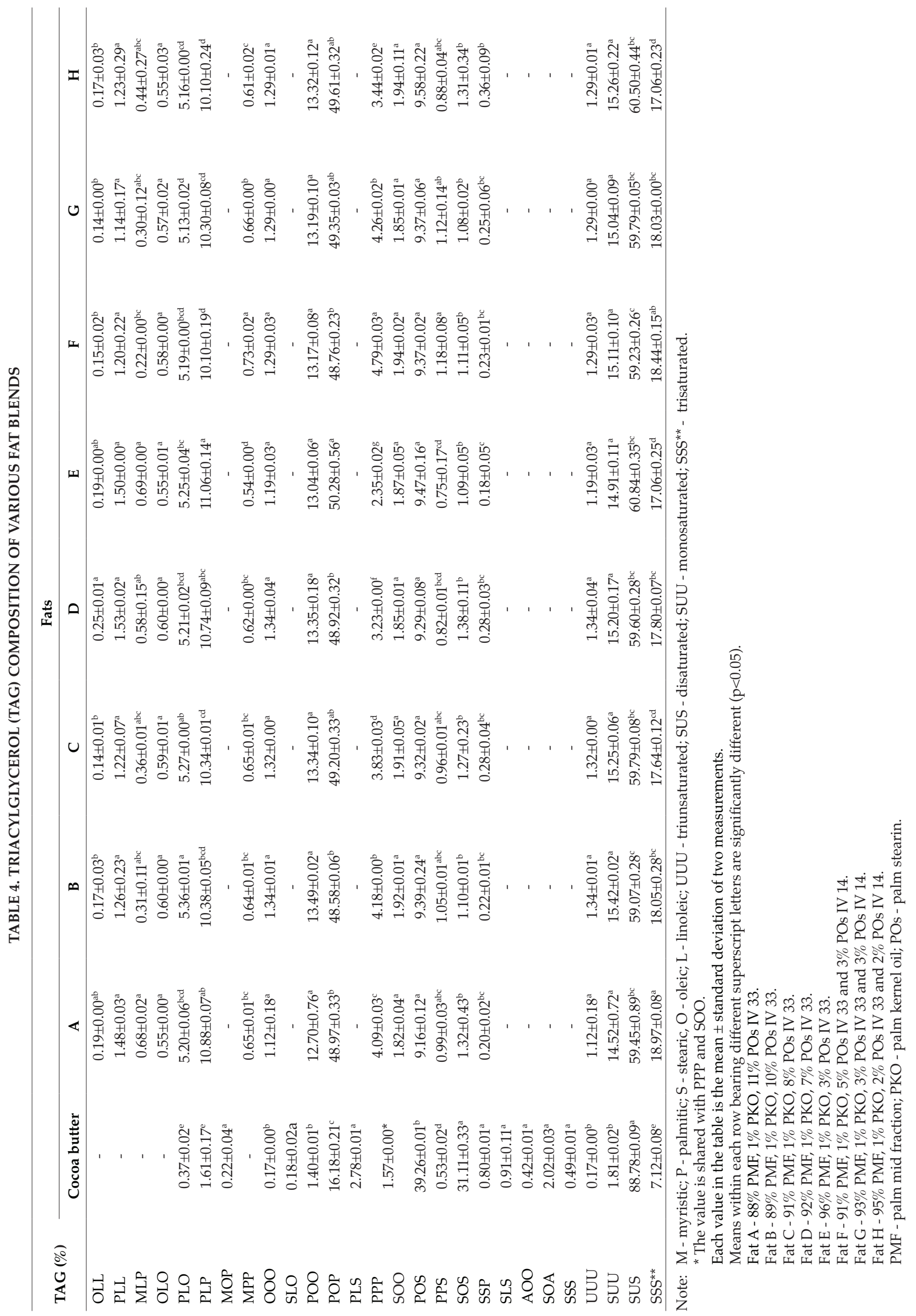


(a)
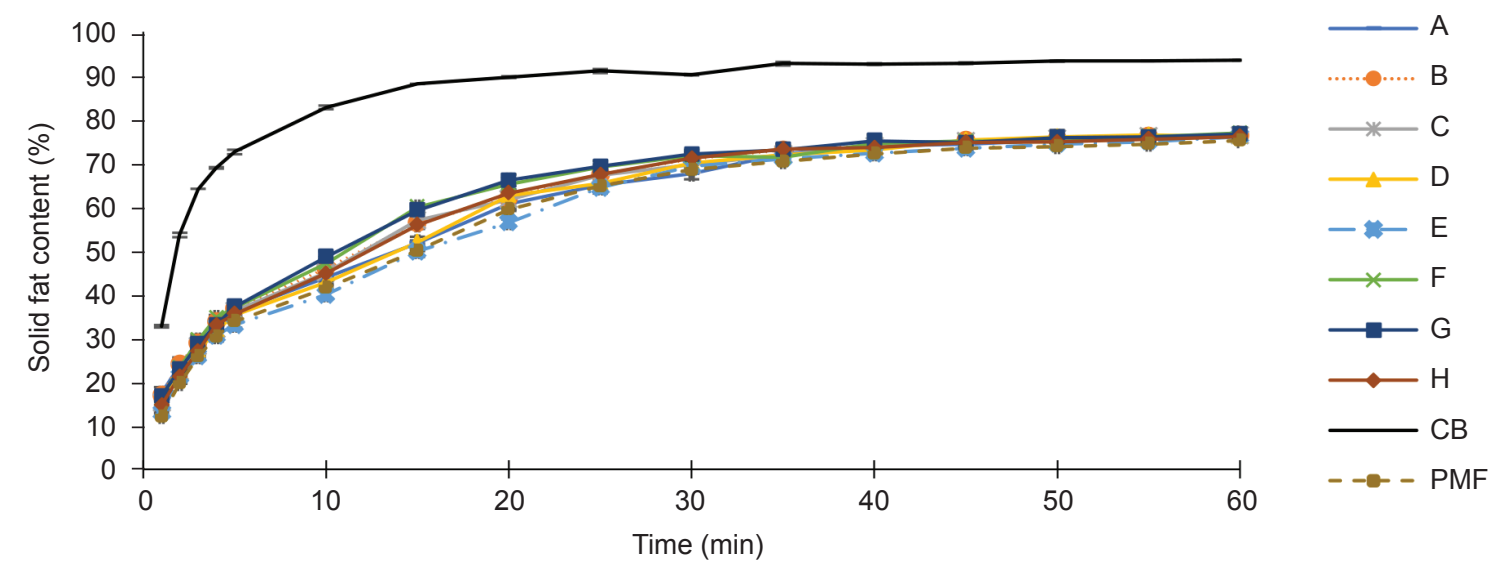

(b)
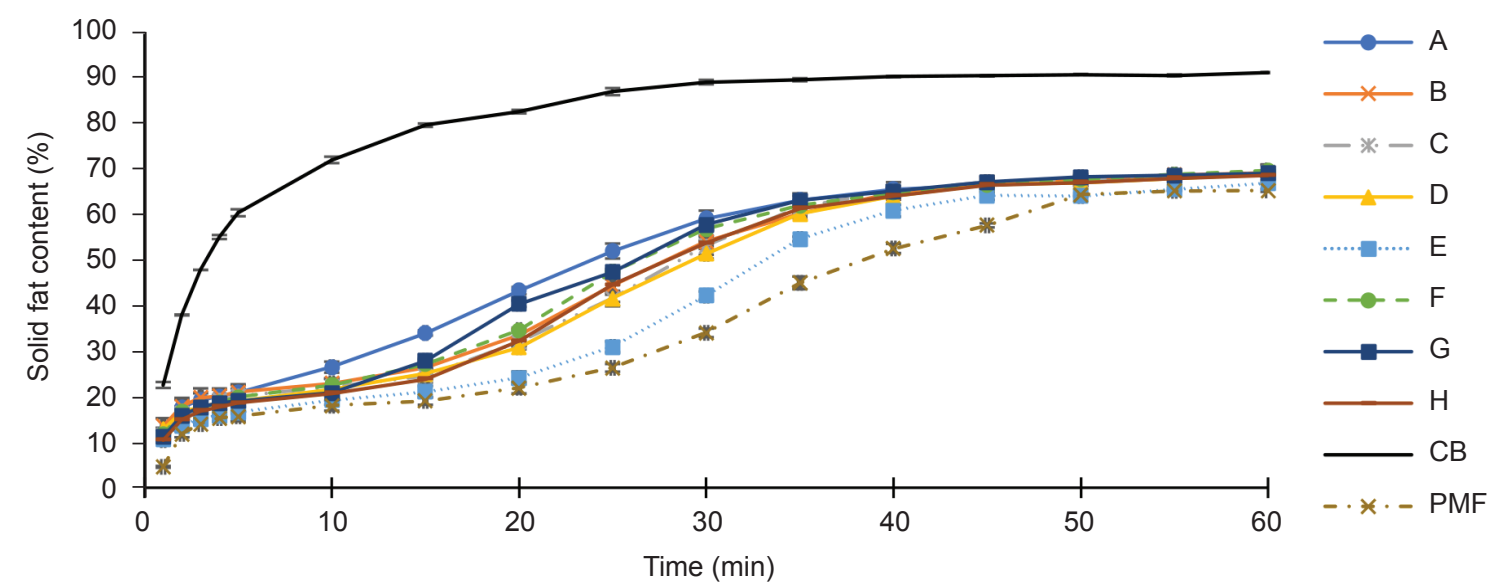

(c)

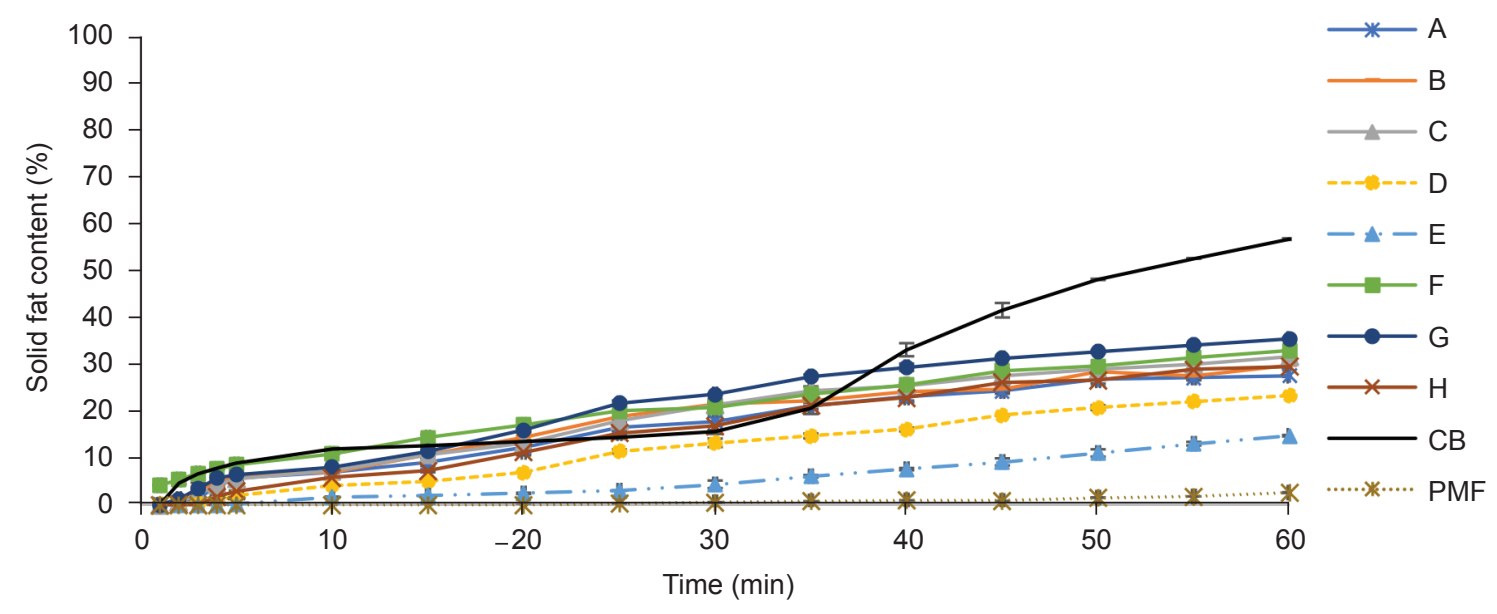

Note: Fat A - 88\% PMF, 1\% PKO, 11\% POs IV 33.

Fat B - 89\% PMF, 1\% PKO, 10\% POs IV 33.

Fat C - 91\% PMF, 1\% PKO, 8\% POs IV 33.

Fat D - 92\% PMF, 1\% PKO, 7\% POs IV 33.

Fat E - 96\% PMF, 1\% PKO, 3\% POs IV 33.

Fat $\mathrm{F}-91 \%$ PMF, 1\% PKO, 5\% POs IV 33 and 3\% POs IV 14.

Fat G - 93\% PMF, 1\% PKO, 3\% POs IV 33 and 3\% POs IV 14

Fat $\mathrm{H}-95 \%$ PMF, 1\% PKO, 2\% POs IV 33 and 2\% POs IV 14.

CB - cocoa butter; PMF - palm mid fraction; PKO - palm kernel oil; POs - palm stearin.

Figure 2. Crystallisation rate of all fats at isothermal temperature of (a) $5^{\circ} \mathrm{C},\left(\right.$ b) $10^{\circ} \mathrm{C}$, and (c) $20^{\circ} \mathrm{C}$. 


\section{Thermal Behaviour}

Thermal melting profiles of all fats are shown in Figure 3. CB produced one sharp thermal melting peak at $22^{\circ} \mathrm{C}$ which is similar to the finding by Sonwai et al. (2014). Two endothermic peaks were observed; low and high melting peaks having sharp and broad peaks, respectively were observed for all the fats. The range of the sharp peaks was from $9.26^{\circ} \mathrm{C}-10.64^{\circ} \mathrm{C}$ while for the broad peak was from $25.38^{\circ} \mathrm{C}-27.89^{\circ} \mathrm{C}$. As all of the fats were PMF dominant, the result was in accordance with the study of PMF by Sonwai et al. (2014) in which PMF produced two distinguished peaks. These fats were observed to have small difference in melting temperatures and were mostly influenced by FAC and TAG compositions (Tables 3 and 4). The low melting peaks may consist of UUU and SUU TAG such as OOO, POO and SOO while the high melting peaks may be an overlapping of saturated-saturated-unsaturated (SSU), SUS and SSS TAG such as PPO and POP for the SSU and SUS TAG and PPP for the SSS TAG. It was observed that the higher the level of PMF in the fats (indicated by fats A-H in Figure 3 having PMF in increasing trend), the low melting peaks shifted more to the left producing slightly lower melting temperature. In addition, lesser POs made the melting curves moved to the left having slightly lower melting temperature too. The broad melting peak may suggest tailing or waxiness to the end product as it may consist of PPP TAG. In general, thermal behaviour of all the fat blends was different from CB. However, they had broad high melting peaks that may assist crystallisation rate and consequently the mouldability property.

\section{Polymorphism}

Crystallisation of a molecule in distinctive configuration of crystal packing is defined as polymorphism. The static crystallisation of $\mathrm{CB}$, PMF, PKO, POs IV 33 and IV 14 and fats A-H at $10^{\circ} \mathrm{C}$ for 30,45 and $60 \mathrm{~min}$ is demonstrated in Figure 4. At $10^{\circ} \mathrm{C}, \mathrm{CB}$ displayed $\beta^{\prime}$ polymorphism having two spacings at $4.2 \AA$ and $3.9 \AA$. Similar findings were reported by Marangoni and McGauley (2003) in which they observed $\beta^{\prime}$ polymorphism for $\mathrm{CB}$ for temperature between $-15^{\circ} \mathrm{C}$ and $20^{\circ} \mathrm{C}$. Three peaks at spacings of $3.8 \AA$, $4.2 \AA$ and $4.3 \AA$ were detected for individual PMF having high percentage of POP. The spacings of $3.8 \AA$ and $4.2 \AA$ demonstrated $\beta^{\prime}$ polymorphism and the spacing of $4.3 \AA$ was approximate of that pseudo- $\beta$ 'configuration (Sonwai et al., 2014). POs IV 33 showed spacings of $4.6 \AA, 4.3 \AA, 4.2 \AA$ and $3.9 \AA$ indicating $\beta^{\prime}$ and $\beta$ polymorphism. POs IV 14 (high in PPP) showed spacing at $4.5 \AA$, 4.1/4.2 $\AA$ and $3.9 \AA$ indicating $\beta^{\prime}$ and $\beta$ polymorphism. PKO (high in LaLaLa) had $\beta^{\prime}$ polymorphism from the spacings of $3.8 \AA, 4.2 \AA$ and $4.4 \AA$ which was similar to the finding by Zhou et al. (2010).

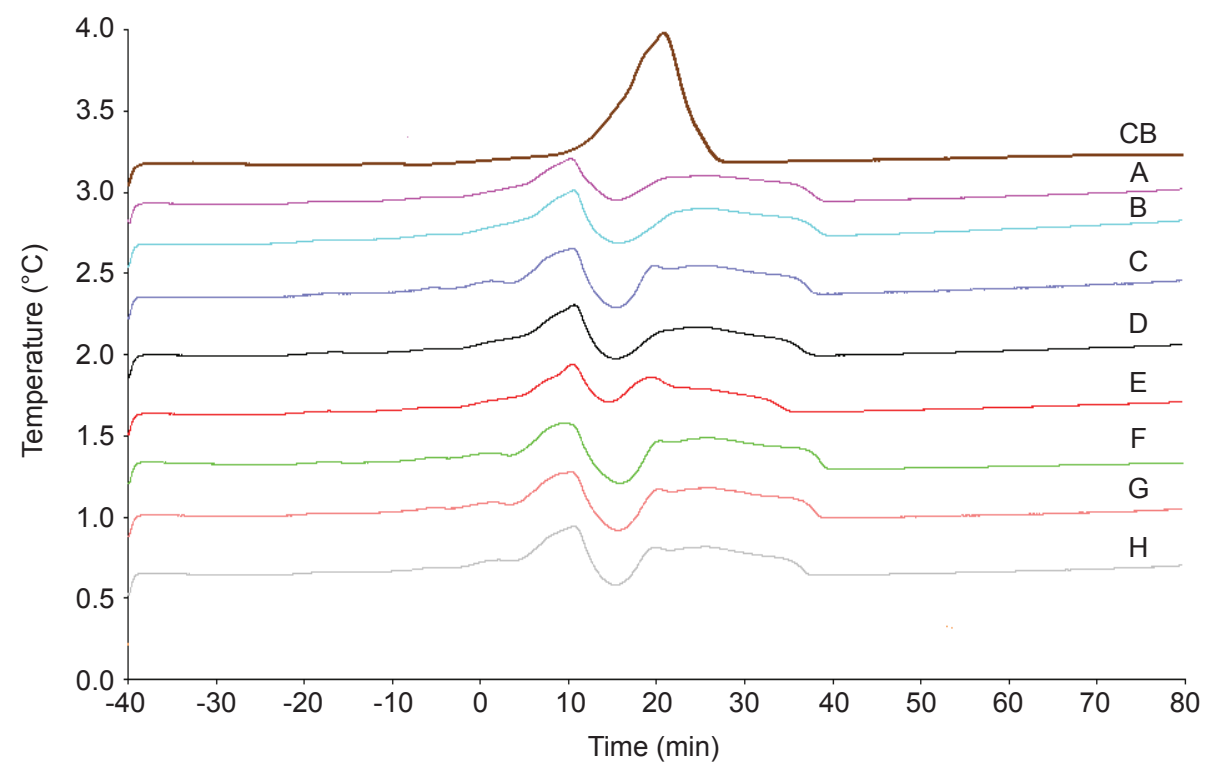

Note: Fat A - 88\% PMF, 1\% PKO, 11\% POs IV 33.

Fat B - 89\% PMF, 1\% PKO, 10\% POs IV 33.

Fat C - 91\% PMF, 1\% PKO, 8\% POs IV 33.

Fat D - 92\% PMF, 1\% PKO, 7\% POs IV 33.

Fat E - 96\% PMF, 1\% PKO, 3\% POs IV 33.

Fat $\mathrm{F}-91 \%$ PMF, 1\% PKO, 5\% POs IV 33 and 3\% POs IV 14.

Fat G - 93\% PMF, 1\% PKO, 3\% POs IV 33 and 3\% POs IV 14.

Fat $\mathrm{H}-95 \%$ PMF, 1\% PKO, 2\% POs IV 33 and 2\% POs IV 14.

$\mathrm{CB}$ - cocoa butter; PMF - palm mid fraction; PKO - palm kernel oil; POs - palm stearin. 
$\beta$ polymorphism is promoted by trisaturated TAG such as PPP (Nusantoro, 2009; Basso et al., 2010) and SSS (Oleivera et al., 2015). Sato (2001b) and Biswas et al. (2017) reported that POP/POS were accountable for $\beta^{\prime}$ polymorphism.

Fats A-H (high in POP) tempered at $10^{\circ} \mathrm{C}$ for 30, 45 and $60 \mathrm{~min}$ (Figures $4 a, b$ and $c$ ) showed $\beta^{\prime}$ polymorphism with spacings of $3.8 \AA$, 4.1/4.2 and $4.3 \AA$ were similar to PMF as PMF was the main fat used in the formulation. Spacing between 3.8$4.3 \AA$ was referred to as having $\beta^{\prime}$ polymorphism (Biswas et al., 2017). The amounts of POs IV 33 and 14 were too small to be detected at spacing of $4.5 / 4.6 \AA$ that represented $\beta$ polymorphism. The physical structure of fats may also change with time at constant temperature because of polymorphic transformations (Metin and Hartel, 2005). However, the experimental time difference in this study may be too short for the polymorphic transformation. In this study, all blended fats were comparable with $\mathrm{CB}$ ( $\beta^{\prime}$ dominance) in terms of polymorphism at $10^{\circ} \mathrm{C}$.

\section{Crystal Morphology}

By using PLM, crystal morphology of individual CB, PMF, POs IV 33, POs IV 14, PKO as well as ternary and quartenary fats of PMF, POs IV 33, POs IV 14 and PKO at $10^{\circ} \mathrm{C}, 20^{\circ} \mathrm{C}$ and $25^{\circ} \mathrm{C}$ were observed (Figures 5-7). Crystallisation of fat is crucial for fat-based product developments particularly in chocolate confectionery. Crystallisation of fat consists of several steps which include primary crystallisation, development of microstructure, formation of continuous 3-dimensional crystal network and finally formation of solid bridge called sintering between aggregated crystals and aggregates (Delbaere et al., 2016).

At $10^{\circ} \mathrm{C}$, all fats including $\mathrm{CB}, \mathrm{PMF}$, POs IV 33, POs IV 14 and PKO showed dense crystal structures. $\mathrm{CB}$ and $\mathrm{PKO}$ had small granular and well dispersed crystal structures. POs IV 33, on the other hand, had rougher but well dispersed crystal structure. PMF showed unclear spherulitic needle-like crystal structure radiating and branching out from the central nucleus due to low temperature. It could be mistaken with granular crystal structure. All of the blended fats did not show much variation in crystal structure and reflected crystal structure of unclear spherulitic needle-like crystal structure radiating and branching out from the central nucleus and granular. Among the blended fats, fat $\mathrm{F}$ had the densest crystal structure due to the addition of POs IV 14. There was a declining trend of crystal packing from fat $\mathrm{A}$ to fat $\mathrm{E}$ as well as from fat $\mathrm{F}$ to fat $\mathrm{H}$ indicating decreasing amounts of POs in the fat blends.

At $20^{\circ} \mathrm{C}$, all fats including $\mathrm{CB}, \mathrm{PMF}, \mathrm{POs}$ IV 33, POs IV 14 and PKO had slightly lost their crystal packing compared to fats at $10^{\circ} \mathrm{C}$. Fats $\mathrm{A}, \mathrm{B}, \mathrm{C}$,
$\mathrm{D}$ and E showed spherulitic needle-like crystal structure radiating and branching out from the central nucleus at $20^{\circ} \mathrm{C}$. This structure became clearer when the level of POs lessened. These fats showed a good trend of decreasing POs IV 33 when these crystals became less dense in packing when only $3 \%$ of POs IV 33 was added to fat E. Similar scenario was observed by Norizzah et al. (2004) when palm kernel olein was added to POs. Structures of evenly distributed small granular crystal were observed in fats $F$ and $G$ due to the addition of POs IV 14. These crystals might be more stable (especially in terms of heat) than other fats as they have denser packing and evenly distributed small crystal structure. Small and dense crystal microstructure might implicate the macroscopic and mechanical attributes of the fat (i.e. hardness) as reported by Bootello et al. (2018) for their sunflower stearin-based CBE. Fat $\mathrm{H}$ having lesser POs IV 14 $(2 \%)$ was less dense in packing compared to fats $\mathrm{F}$ and $\mathrm{G}$.

Spherulitic needle-like crystals structure was observed in commercial $\mathrm{CB}$ at $25^{\circ} \mathrm{C}$. The structure was similar to the findings by Sonwai et al. (2014). Bigger and clearer spherulitic needle-like crystals structure was observed in PMF. Granular crystals were observed for POs IV 33 and POs IV 14. Granular crystals of POs IV 14 were observed to have denser packing. The morphology of PKO displayed feather-like crystals. It was observed that the crystal structure of fats A, B, C, D and E were quite similar to one another having spherulitic needlelike crystal structure radiating and branching out from the central nucleus. However, they were different in terms of crystal packing depending on the amounts of POs IV 33. Notwithstanding this, similar crystal structures were found at $20^{\circ} \mathrm{C}$ with less dense packing. Fats F, G and $\mathrm{H}$ also showed spherulitic needle-like crystal structure radiating and branching out from the central nucleus. However, the nucleus of the structure had become larger. The decremental addition of POs IV 33 and IV 14 to PMF led to the development of large and loosely packed crystals. Fat F showed the densest crystal packing compared to other fats. According to Delbaere et al. (2016), a denser crystal packing in chocolate reduced overall mobility of fat resulting to the decreased rate of oil migration.

It can be concluded that crystal structure for all fats at temperatures of $10^{\circ} \mathrm{C}, 20^{\circ} \mathrm{C}$ and $25^{\circ} \mathrm{C}$ varied from one to another. The disparity might be due to different TAG (Table 4) composition and distinct textural properties of PMF, PKO and POs IV 33 and IV 44 (Çiftçi et al., 2009) which relates to the chemical composition of the fat as well as temperature. In addition, crystal size is dependent on temperature history. The packing (density) of fat $\mathrm{F}$ was comparable with $\mathrm{CB}$ and therefore, might impose good mouldability property. 
(a)

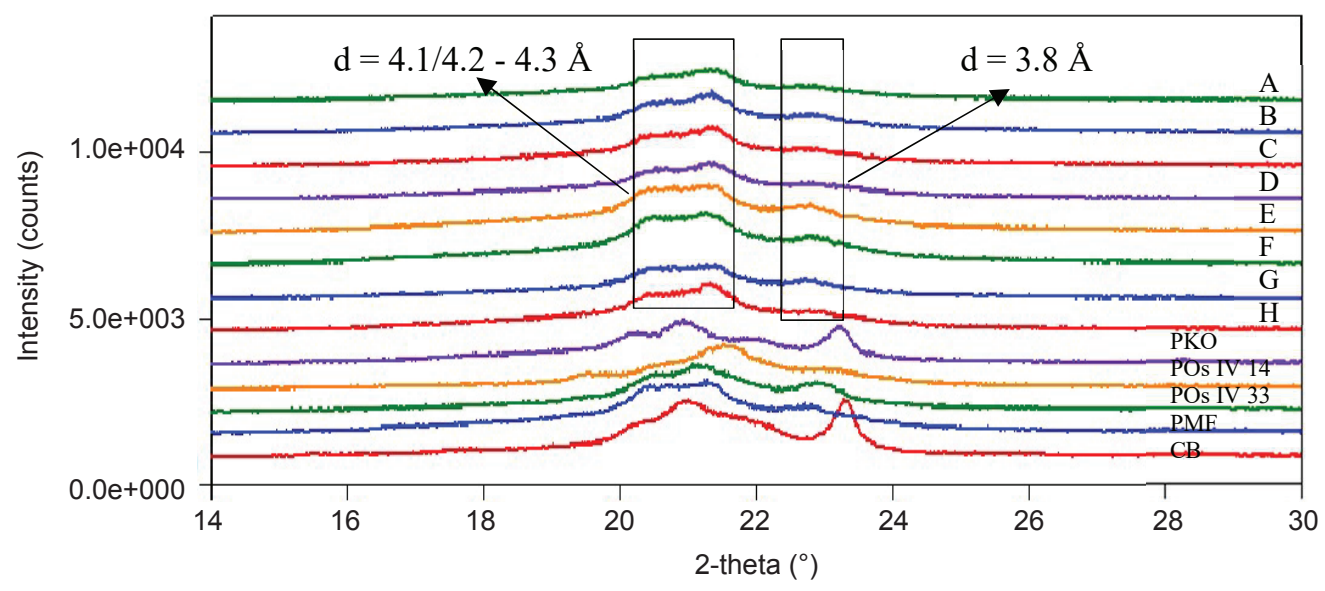

(b)

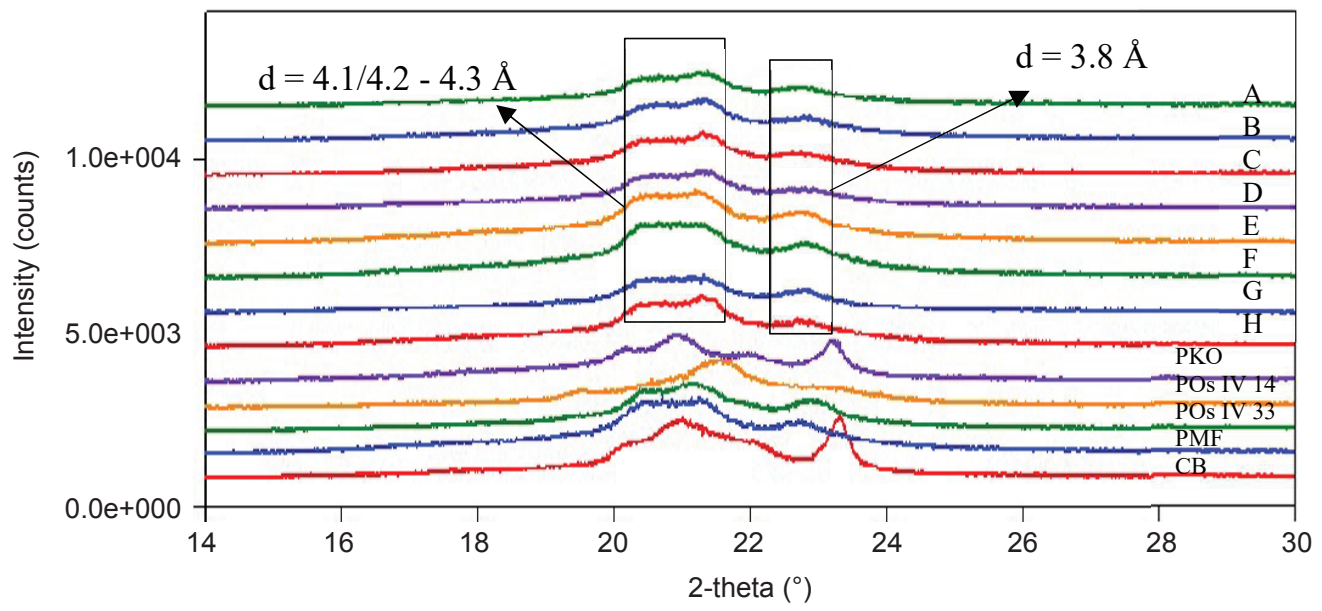

(c)

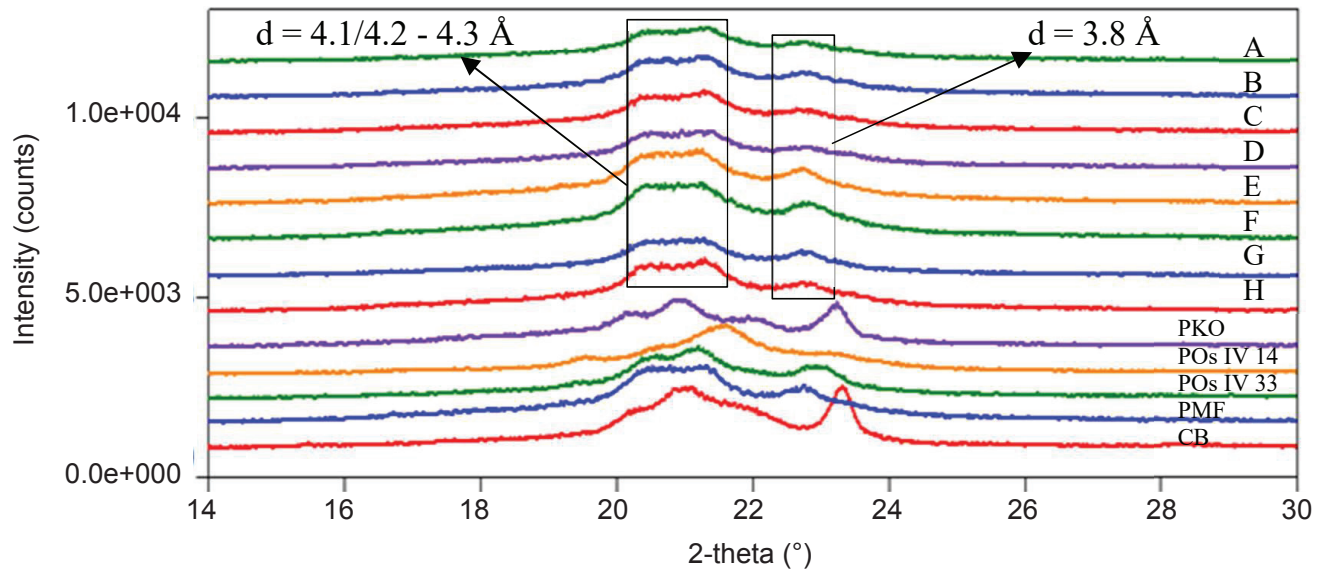

Note: Fat A - 88\% PMF, 1\% PKO, 11\% POs IV 33.

Fat B - 89\% PMF, 1\% PKO, 10\% POs IV 33.

Fat C - 91\% PMF, 1\% PKO, 8\% POs IV 33.

Fat D - 92\% PMF, $1 \%$ PKO, $7 \%$ POs IV 33.

Fat E - 96\% PMF, 1\% PKO, 3\% POs IV 33.

Fat $\mathrm{F}-91 \%$ PMF, 1\% PKO, 5\% POs IV 33 and 3\% POs IV 14

Fat G - 93\% PMF, 1\% PKO, 3\% POs IV 33 and 3\% POs IV 14.

Fat $\mathrm{H}-95 \%$ PMF, 1\% PKO, 2\% POs IV 33 and 2\% POs IV 14.

PKO - palm kernel oil; POs - palm stearin; PMF - palm mid fraction; CB - cocoa butter.

Figure 4. Polymorphism of all fats at (a) $30 \mathrm{~min}$, (b) $45 \mathrm{~min}$, and (c) $60 \mathrm{~min}$. 

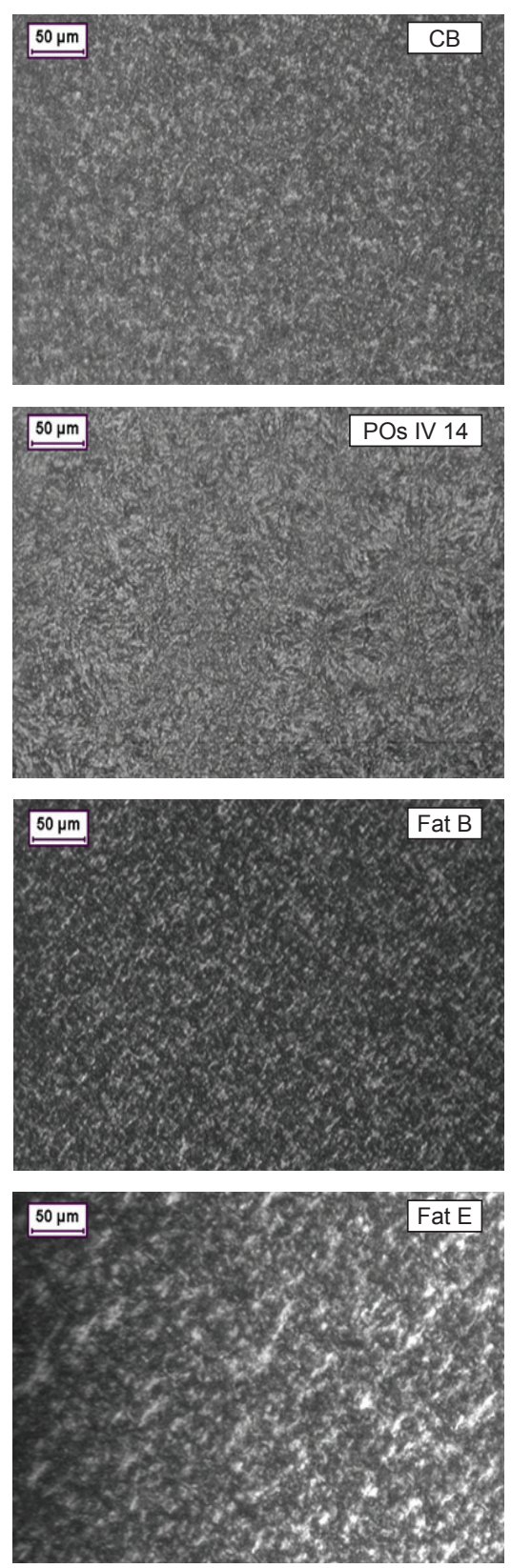
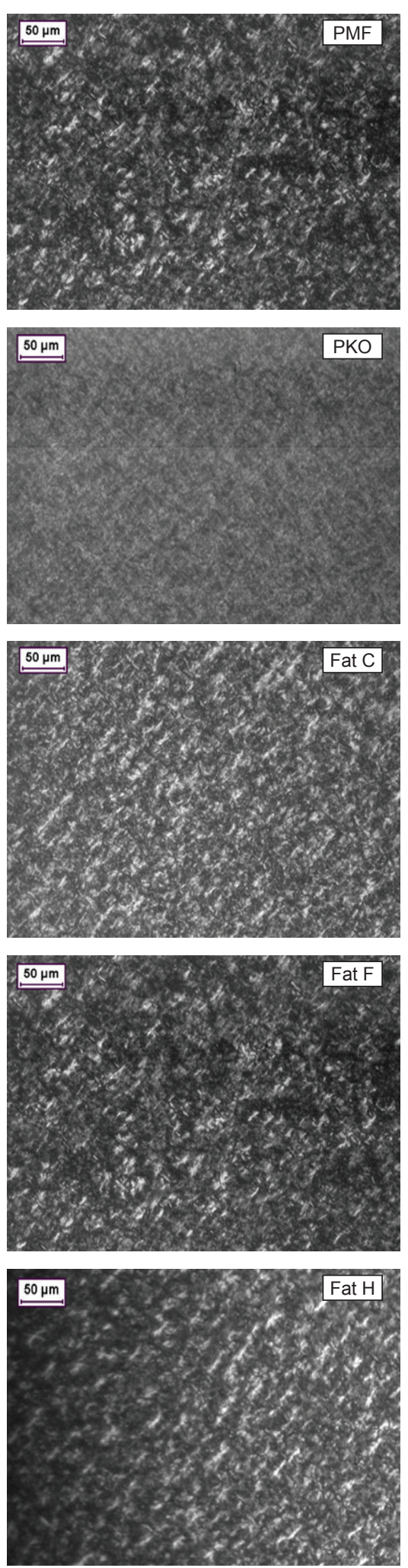
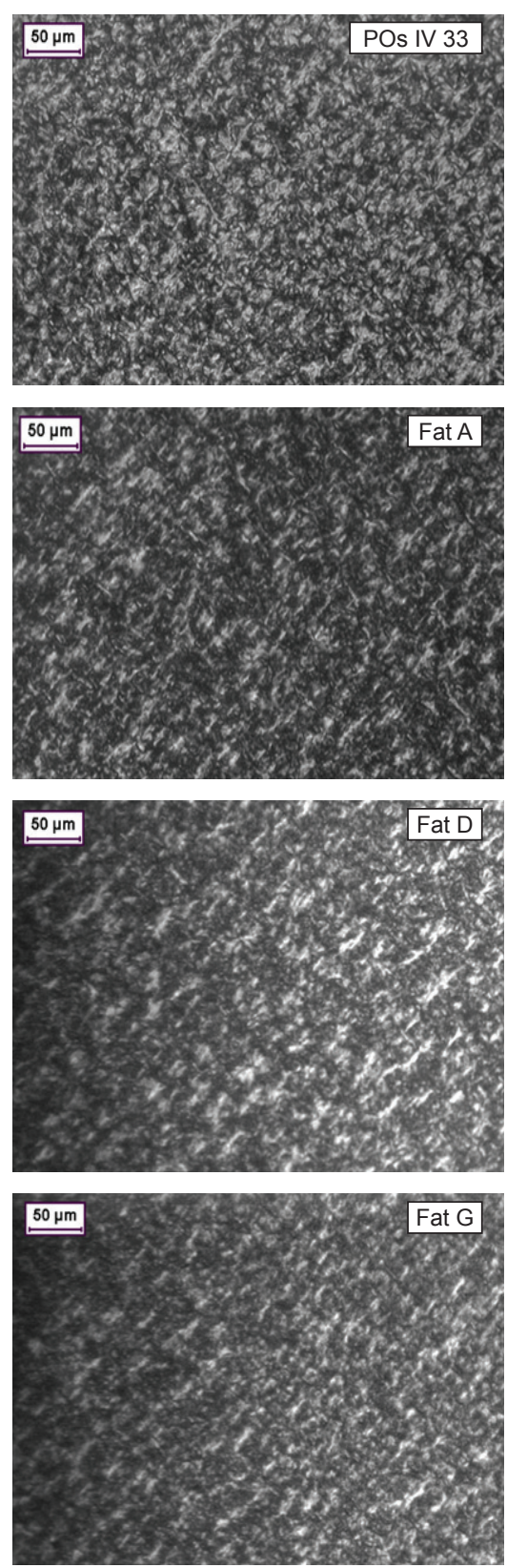

\footnotetext{
(1)

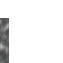



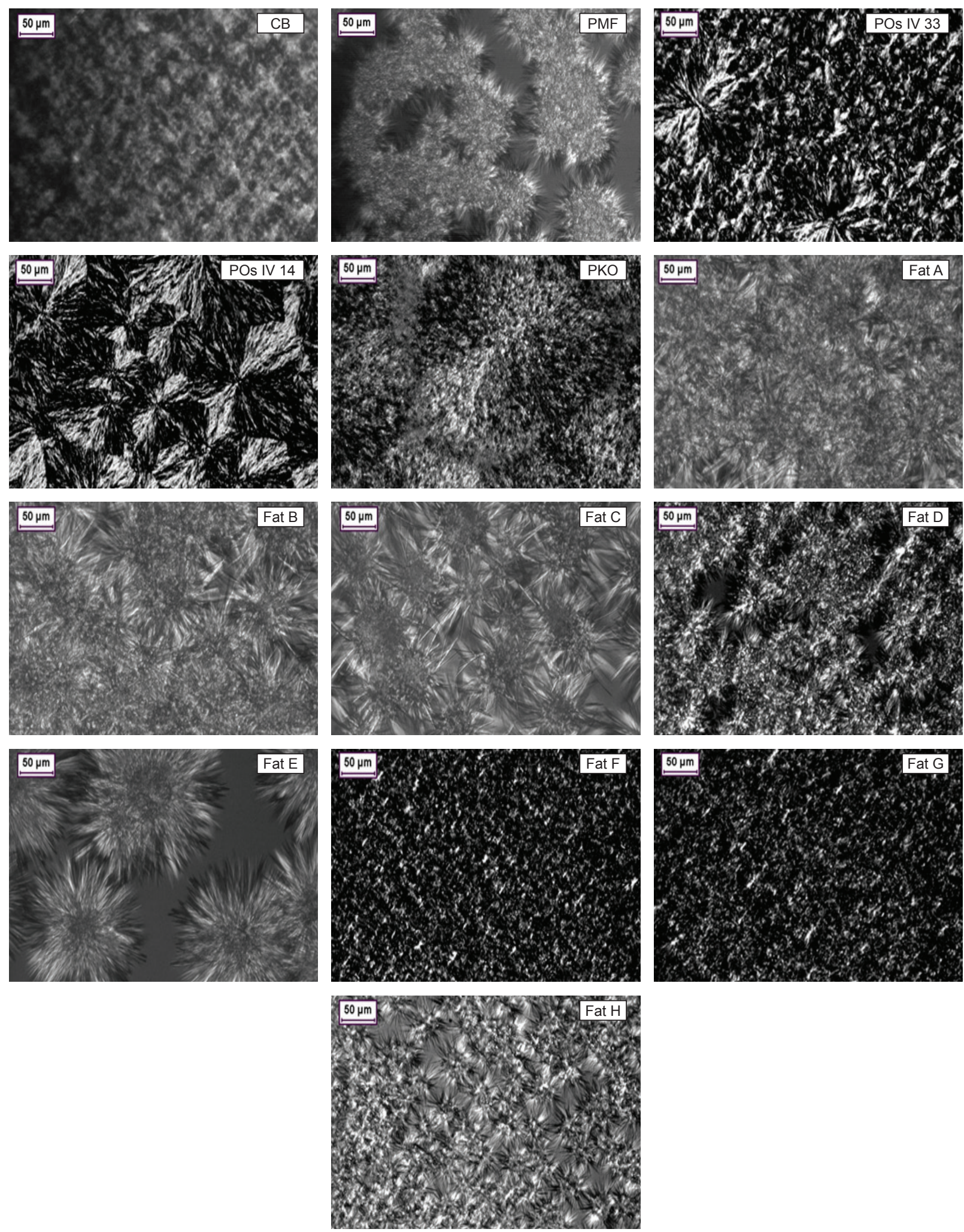

Note: Fat A - $88 \%$ PMF, $1 \%$ PKO, 11\% POs IV 33.

Fat B - 89\% PMF, 1\% PKO, 10\% POs IV 33

Fat C - 91\% PMF, 1\% PKO, 8\% POs IV 33.

Fat D - 92\% PMF, 1\% PKO, 7\% POs IV 33.

Fat E - 96\% PMF, 1\% PKO, 3\% POs IV 33.

Fat $\mathrm{F}-91 \%$ PMF, 1\% PKO, 5\% POs IV 33 and $3 \%$ POs IV 14.

Fat G - 93\% PMF, 1\% PKO, 3\% POs IV 33 and 3\% POs IV 14

Fat $\mathrm{H}-95 \%$ PMF, 1\% PKO, 2\% POs IV 33 and 2\% POs IV 14.

PMF - palm mid fraction; POs - palm stearin; PKO - palm kernel oil; CB - cocoa butter.

Figure 6. Polarised light micrographs (x20 lens) of cocoa butter, PMF, POs IV 33, POs IV 14, PKO and fats A-H at $20^{\circ} \mathrm{C}$. 

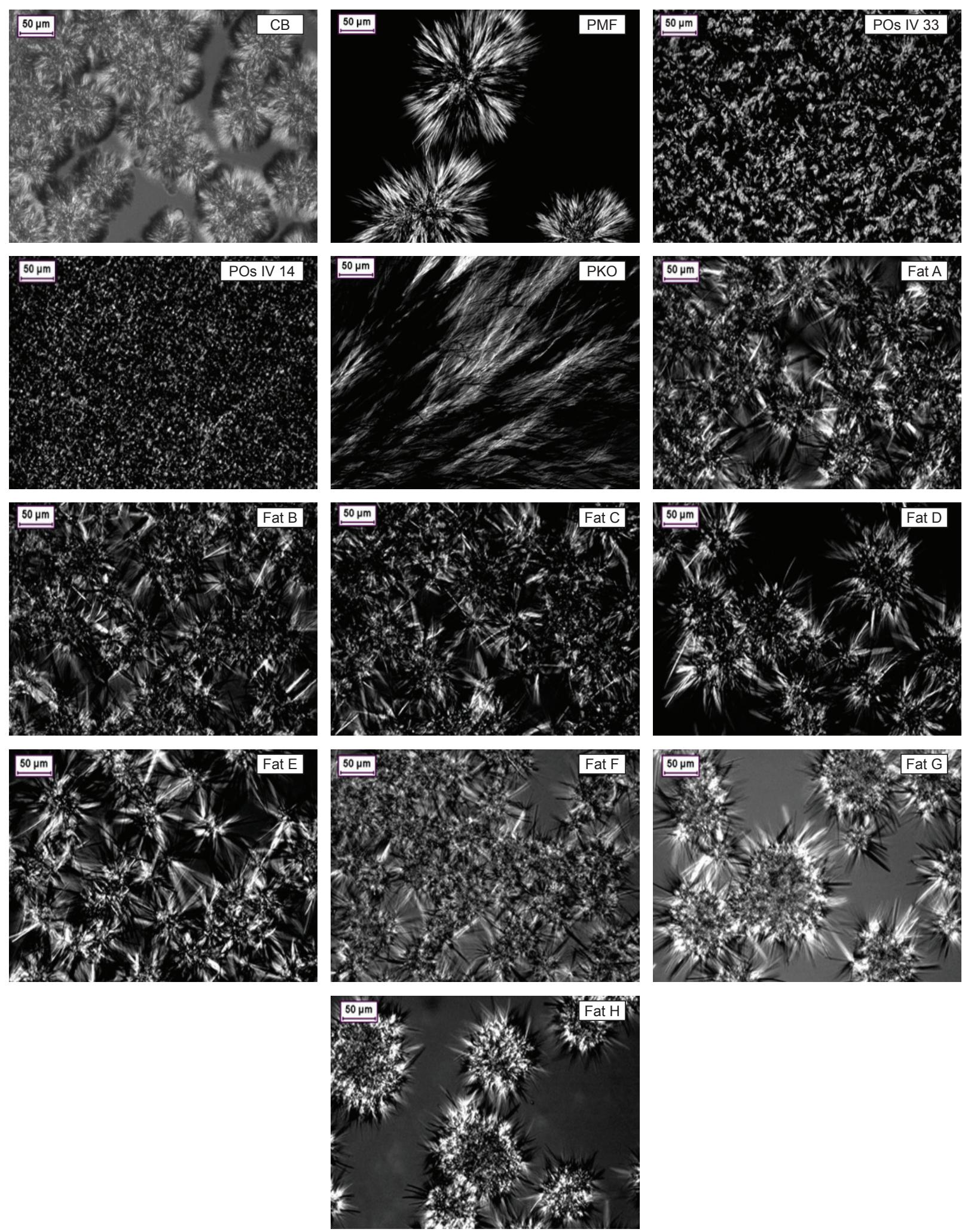

Note: Fat A - 88\% PMF, 1\% PKO, 11\% POs IV 33.

Fat B - 89\% PMF, 1\% PKO, 10\% POs IV 33

Fat C - 91\% PMF, 1\% PKO, 8\% POs IV 33.

Fat D - 92\% PMF, 1\% PKO, 7\% POs IV 33.

Fat E - 96\% PMF, 1\% PKO, 3\% POs IV 33.

Fat $\mathrm{F}-91 \%$ PMF, $1 \%$ PKO, $5 \%$ POs IV 33 and $3 \%$ POs IV 14.

Fat G - 93\% PMF, 1\% PKO, 3\% POs IV 33 and 3\% POs IV 14.

Fat $\mathrm{H}-95 \%$ PMF, 1\% PKO, 2\% POs IV 33 and 2\% POs IV 14.

PMF - palm mid fraction; POs - palm stearin; PKO - palm kernel oil; CB - cocoa butter.

Figure 7. Polarised light micrographs (x20 lens) of cocoa butter, PMF, POs IV 33, POs IV 14, PKO and fats A-H at $25^{\circ} \mathrm{C}$. 


\section{Mouldability}

Table 5 shows the mouldability of chocolate bars from all blended fats at cooling time of 30, 45 and 60 min. Cooling temperature of $10^{\circ} \mathrm{C}-15^{\circ} \mathrm{C}$ is typically used by commercial chocolate manufacturers (CBbased) but cooling temperature of $10^{\circ} \mathrm{C}$ is normally required to eliminate the sensible and latent heat from the liquid chocolate for easy demoulding in order to produce solid chocolate product. The time needed for cooling and solidification relies upon the temperature of the cooling air which translates as the rate of heat transfer from chocolate product to air (Keijbets et al., 2010). The solidification of chocolate that relates to crystal structure renders the hardness of chocolate (Jahurul et al., 2013) and subsequently influences its mouldability.

Chocolate bars prepared from $\mathrm{CB}$ and palmbased CBA are able to be moulded and demoulded between 15-20 min (Keijbets et al., 2010; MPOC, 2006; Bolliger et al., 1998). However, chocolate bars from the blended fats were unable to be demoulded even at $30 \mathrm{~min}$ of cooling time. Despite of this, chocolate bars from all blended fats were able to be demoulded at 45 and $60 \mathrm{~min}$ of cooling time without fracture. Although polymorphism of all fats observed using XRD that were conditioned for 30, 45 and $60 \mathrm{~min}$ at $10^{\circ} \mathrm{C}$ showed $\beta^{\prime}$ dominance, the mouldability outcome varied in which chocolate bars from all of the blended fats were mouldable at 45 and $60 \mathrm{~min}$ but was not mouldable at $30 \mathrm{~min}$. Solidification time which relates to crystallisation rate plays important role in this scenario. Figure 2 demonstrates that at 40$45 \mathrm{~min}$ of crystallisation at isothermal temperature of $10^{\circ} \mathrm{C}$, all fats showed overlapping SFC (approximate value of $65 \%-70 \% \mathrm{SFC}$ ) and began to plateau indicating equilibrium phase had been reached. Therefore, they may be able to be moulded and demoulded easily. Optimised cooling time for all the fats was at $45 \mathrm{~min}$ at isothermal temperature of $10^{\circ} \mathrm{C}$ due to complete crystallisation. Prolonging the crystallisation time gave similar mouldability result to 45 min crystallisation time. In addition, all of the eight fat blends regardless of formulations were able to produce similar mouldability result. However, crystal morphology among all fats were dissimilar which may influence the snappability. In addition, Wainwright (1996) reported that CBS that has higher crystallisation rate compared to CBR imposes rapid crystallisation and has better manufacturing advantage than CBR.

\section{Mechanical Resistance (Snappability)}

Table 6 shows the snappability value (rupture tension and breaking force) of chocolate bars from various blended fats at cooling time of 45 and $60 \mathrm{~min}$ at $10^{\circ} \mathrm{C}$ right after demoulding as the chocolate bars at 45 and 60 min were able to be demoulded without being fractured. Chocolate bars prepared at cooling time of $30 \mathrm{~min}$ were omitted as they fractured during demoulding process at $10^{\circ} \mathrm{C}$. The snappability of chocolate bars at 45 and 60 min was significantly different from each other $(p<0.05)$. However, fats A, B, C, D, G and $\mathrm{H}$ were insignificantly different from each other $(p>0.05)$ at $60 \mathrm{~min}$. Fat F produced the highest rupture tension and breaking force both at 45 and $60 \mathrm{~min}$ of chocolate bars at $10^{\circ} \mathrm{C}$ while fat $\mathrm{E}$ showed the lowest values for both parameters. The rupture tension of chocolate bars of fat $\mathrm{F}$ at 45 and $60 \mathrm{~min}$ were $105.28 \mathrm{~g}_{\mathrm{f}} \mathrm{cm}^{-2}$ and $107.92 \mathrm{~g}_{\mathrm{f}} \mathrm{cm}^{-2}$, respectively while the breaking force of fat $\mathrm{F}$ at 45 and $60 \mathrm{~min}$ were $5501 \mathrm{~g}_{\mathrm{f}}$ and $5639 \mathrm{~g}_{\mathrm{f}}$, respectively. Fat F had the densest crystal structure compared to other fats at $10^{\circ} \mathrm{C}$ and had influenced on the snappability value.

The addition, POs IV 33 and POs IV 14 significantly influenced the snappability values when compared to $100 \%$ PMF (having the lowest snappability value). Therefore, the addition of POs IV 33 and POs IV 14 influenced the snappability value of the chocolate bar. Increasing trend of snappability values were observed with increasing amount of added POs IV 33 and POs IV 14. However, the increase in snappability value became more prominent when POs IV 14 was added. This also showed that POs IV 33 and POs IV 14 are chemically compatible with PMF. Snappability of chocolate is associated to ingredients in the formulation (Quast et al., 2011) which consequently relates to the mechanical strength of network of fat crystal (Smith, 2009; Marangoni, 2002). Minor changes in the TAG composition can give huge impact on its crystallisation and further development of the fat structure (De Graef et al., 2012; Himawan et al., 2006 and Sato, 2001a). Incompatible fats such as blend of $\mathrm{CB}$ with lauric-based CBS showed decreased snappability value due to incompatibily between TAG as has been reported in many articles including Quast et al. (2013). Right crystal formation and its homogeneity also influenced snappability as reported by Rowat et al. (2011).

According to Timms (2003), chocolate should be crystalline at $20^{\circ} \mathrm{C}$ and therefore will impart good snappability. However, all of the chocolate using fats $\mathrm{A}-\mathrm{H}$ had difficulties to retain their shape at $20^{\circ} \mathrm{C}$ and therefore, the best fat having highest rupture tension and breaking force at $10^{\circ} \mathrm{C}$ (fat F) was blended with CB.

\section{Compatibility with Cocoa Butter}

The compatibility of fat $\mathrm{F}$ and $\mathrm{CB}$ at $20^{\circ} \mathrm{C}$ is illustrated in Figure 8. Compatibility of fats refers to eutecticity (softening) when different types of molecular volume, shape and polymorph are found for each fat (Gold et al., 2011). Fat F was found to be fully miscible with $\mathrm{CB}$ with no 
significant eutecticity observed except for dilution and dissolution effect. However, $70 \%$ and $80 \%$ addition of fat $\mathrm{F}$ to $\mathrm{CB}$ showed minor lowering of SFC. Addition of $10 \%-30 \%$ of fat $\mathrm{F}$ to CB provided the best mixtures as there were no lowering of SFC observed and they had high SFC as well. Sonwai et al. (2014) reported that their blended CBE from mango kernel fat and PMF with $\mathrm{CB}$ having a decreasing trend of SFC with different CBE/CB ratio as being fully compatible and does not show any sign of eutecticity. Jeyarani and Reddy (1999) also reported that their mixtures of kokum fat and mahua stearin which showed an increasing trend of SFC as fully compatible with each other with no major changes in solid phase or melting range other than changes in dilution and dissolution. Fat F $(30 \%)$ and CB (70\%) was able to be demoulded by $30 \mathrm{~min}$ and produced snappability (breaking force) of $5032.71 \pm 85.91 \mathrm{~g}_{\mathrm{f}}$ at $20^{\circ} \mathrm{C}$ after one day stabilisation period.

TABLE 5. MOULDABILITY OF CHOCOLATE BARS AT COOLING TIME OF 30 MIN, 45 MIN AND 60 MIN AT $10^{\circ} \mathrm{C}$

\begin{tabular}{cccc}
\hline Fat & Cooling time 30 min & Cooling time $\mathbf{4 5}$ min & Cooling time 60 min \\
\hline A & Not mouldable & Mouldable & Mouldable \\
B & Not mouldable & Mouldable & Mouldable \\
C & Not mouldable & Mouldable & Mouldable \\
D & Not mouldable & Mouldable & Mouldable \\
E & Not mouldable & Mouldable & Mouldable \\
F & Not mouldable & Mouldable & Mouldable \\
G & Not mouldable & Mouldable & Mouldable \\
H & Not mouldable & Mouldable & Mouldable \\
\hline
\end{tabular}

Note: Score reading is average of three replicates.

Fat A - 88\% PMF, 1\% PKO, 11\% POs IV 33.

Fat B - 89\% PMF, 1\% PKO, 10\% POs IV 33.

Fat C - 91\% PMF, 1\% PKO, 8\% POs IV 33.

Fat D - $92 \%$ PMF, 1\% PKO, $7 \%$ POs IV 33.

Fat E - 96\% PMF, 1\% PKO, 3\% POs IV 33.

Fat $\mathrm{F}-91 \%$ PMF, 1\% PKO, 5\% POs IV 33 and 3\% POs IV 14.

Fat G- 93\% PMF, 1\% PKO, 3\% POs IV 33 and 3\% POs IV 14.

Fat $\mathrm{H}-95 \%$ PMF, 1\% PKO, 2\% POs IV 33 and 2\% POs IV 14.

PMF - palm mid fraction; $\mathrm{CB}$ - cocoa butter; $\mathrm{PKO}$ - palm kernel oil; POs - palm stearin.

TABLE 6. RUPTURE TENSION AND BREAKING FORCE OF CHOCOLATE BARS AT COOLING TIME OF 45 MIN AND 60 MIN AT $10^{\circ} \mathrm{C}$

\begin{tabular}{|c|c|c|c|c|}
\hline \multirow[b]{2}{*}{ Fat } & \multicolumn{2}{|c|}{$45 \mathrm{~min}$} & \multicolumn{2}{|c|}{$60 \mathrm{~min}$} \\
\hline & $\begin{array}{l}\text { Rupture tension } \\
\qquad\left(\mathrm{g}_{\mathrm{f}} \mathrm{cm}^{-2}\right)\end{array}$ & $\begin{array}{c}\text { Breaking force } \\
\left(\mathrm{g}_{\mathrm{f}}\right)\end{array}$ & $\begin{array}{l}\text { Rupture tension } \\
\qquad\left(\mathrm{g}_{\mathrm{f}} \mathrm{cm}^{-2}\right)\end{array}$ & $\begin{array}{l}\text { Breaking force } \\
\left(g_{f}\right)\end{array}$ \\
\hline A & $86.81 \pm 11.22^{\mathrm{bcd}}$ & $4536 \pm 586^{\mathrm{bcd}}$ & $93.57 \pm 2.56^{b c}$ & $4889 \pm 134^{\mathrm{bc}}$ \\
\hline B & $85.45 \pm 7.81^{\text {cde }}$ & $4465 \pm 408^{\text {cde }}$ & $88.11 \pm 6.26^{\mathrm{bc}}$ & $4604 \pm 327^{\mathrm{bc}}$ \\
\hline C & $74.91 \pm 1.61^{\text {def }}$ & $3914 \pm 84^{\text {def }}$ & $84.25 \pm 4.82^{b c}$ & $4402 \pm 252^{\mathrm{bc}}$ \\
\hline $\mathrm{D}$ & $72.63 \pm 1.59^{\mathrm{ef}}$ & $3795 \pm 83^{\text {ef }}$ & $83.23 \pm 6.72^{b c}$ & $4349 \pm 351^{\mathrm{bc}}$ \\
\hline $\mathrm{E}$ & $67.37 \pm 3.69^{f}$ & $3520 \pm 193^{f}$ & $81.97 \pm 7.58^{c}$ & $4283 \pm 396^{c}$ \\
\hline $\mathrm{F}$ & $105.28 \pm 6.51^{\mathrm{ab}}$ & $5501 \pm 340^{\mathrm{ab}}$ & $107.92 \pm 4.42^{\mathrm{b}}$ & $5639 \pm 231^{b}$ \\
\hline G & $92.06 \pm 1.00^{\mathrm{bcd}}$ & $4810 \pm 52^{\mathrm{bcd}}$ & $95.08 \pm 0.80^{\mathrm{bc}}$ & $4968 \pm 42^{\mathrm{bc}}$ \\
\hline $\mathrm{H}$ & $86.33 \pm 3.37^{b c}$ & $4511 \pm 176^{\mathrm{bc}}$ & $92.27 \pm 7.77^{\mathrm{bc}}$ & $4821 \pm 406^{\mathrm{bc}}$ \\
\hline PMF & $66.26 \pm 4.34^{\mathrm{f}}$ & $3462 \pm 227^{\mathrm{f}}$ & $91.41 \pm 4.00^{\mathrm{bc}}$ & $4776 \pm 209^{\mathrm{bc}}$ \\
\hline $\mathrm{CB}$ & $121.44 \pm 8.56^{\mathrm{a}}$ & $6345 \pm 447^{\mathrm{a}}$ & $162.39 \pm 20.84^{\mathrm{a}}$ & $8485 \pm 1089^{a}$ \\
\hline
\end{tabular}

Note: Score reading is average of three replicates.

Means within each row bearing different superscript letters are significantly different $(p<0.05)$.

Fat A - 88\% PMF, 1\% PKO, 11\% POs IV 33.

Fat B - $89 \%$ PMF, 1\% PKO, 10\% POs IV 33.

Fat C - 91\% PMF, 1\% PKO, 8\% POs IV 33.

Fat D - 92\% PMF, 1\% PKO, 7\% POs IV 33.

Fat E - 96\% PMF, 1\% PKO, 3\% POs IV 33.

Fat $\mathrm{F}-91 \%$ PMF, 1\% PKO, 5\% POs IV 33 and 3\% POs IV 14.

Fat G - 93\% PMF, 1\% PKO, 3\% POs IV 33 and 3\% POs IV 14.

Fat $\mathrm{H}-95 \%$ PMF, 1\% PKO, 2\% POs IV 33 and 2\% POs IV 14.

PMF - palm mid fraction; CB - cocoa butter; PKO - palm kernel oil; POs - palm stearin. 


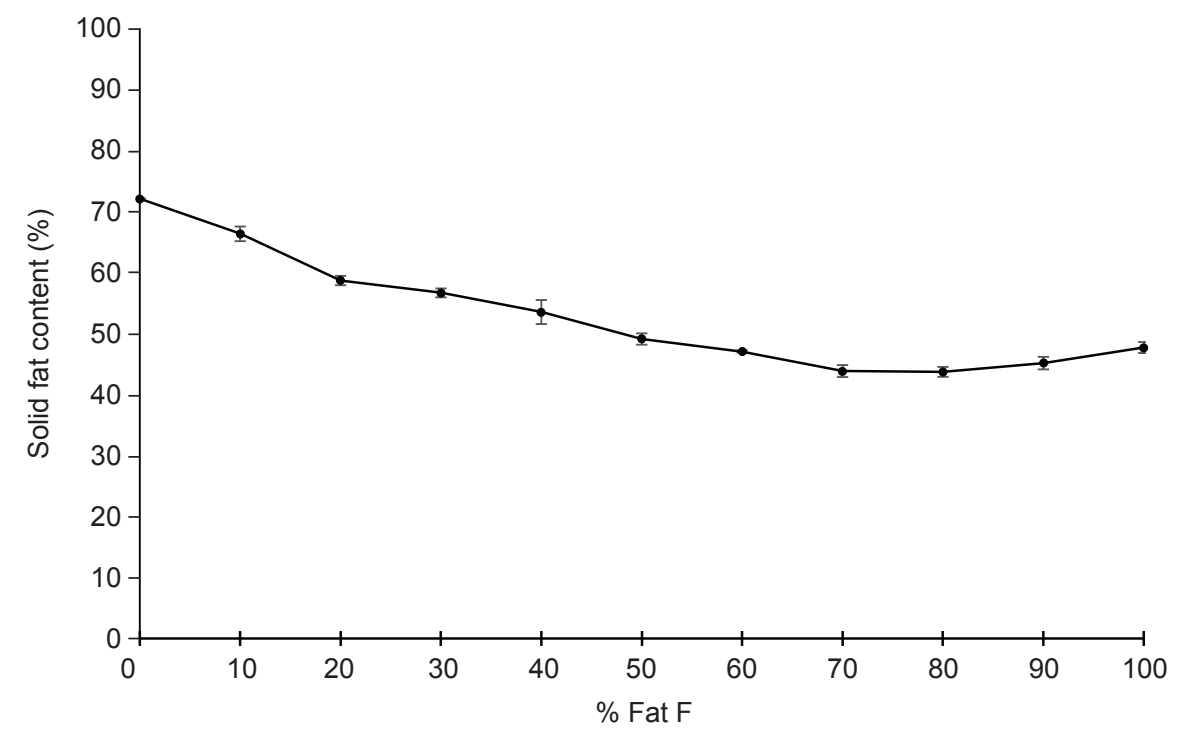

Figure 8. Compatilibity of fat $F(91 \%$ palm mid fraction: $1 \%$ palm kernel oil: $5 \%$ palm stearin IV 33: $3 \%$ palm stearin IV 14) with cocoa butter at $20^{\circ} \mathrm{C}$.

\section{CONCLUSION}

Eight fat blends namely A) $88 \%$ PMF, $1 \%$ PKO, $11 \%$ POs IV 33, B) 89\% PMF, 1\% PKO, 10\% POs IV 33, C) 91\% PMF, 1\% PKO, 8\% POs IV 33, D) 92\% PMF, $1 \%$ PKO, 7\% POs IV 33, E) 96\% PMF, 1\% PKO, 3\% POs IV 33, F) 91\% PMF, 1\% PKO, 5\% POs IV 33 and 3\% POs IV 14 G) 93\% PMF, 1\% PKO, 3\% POs IV 33 and 3\% POs IV 14, H) 95\% PMF, 1\% PKO, 2\% POs IV 33 and $2 \%$ POs IV 14 of CBA from palm-based fractions (PMF, PKO, POs IV 33 and 14) have been identified through optimised ternary blends. Chocolate bar produced from these blended palm fractions were able to be moulded and demoulded at 45 and 60 min at cooling temperature of $10^{\circ} \mathrm{C}$ with optimised time of $45 \mathrm{~min}$. The addition of POs IV 33 and IV 14 increased the snappability (rupture tension and breaking force) of all fat blends progressively. Blend of 91\% PMF: 1\% PKO: 5\% POs IV 33: 3\% POs IV 14 (Fat F) was observed to have the highest snap value at $10^{\circ} \mathrm{C}$. It has comparable oleic acid content, linoleic acid content, monounsaturated fatty acid content, crystal morphology (density) as well as SFC profile at $20^{\circ} \mathrm{C}$ and crystallisation rate profile at $5^{\circ} \mathrm{C}, 10^{\circ} \mathrm{C}$ (after $40^{\text {th }} \mathrm{min}$ ) and $20^{\circ} \mathrm{C}$ (before $35^{\text {th }}$ min) with $\mathrm{CB}$ with dissimilarity in other FAC, TAG, melting behaviour and polymorphism. Therefore, this blend is the most potential CBA to be used as fat for chocolate bar. However, its SFC at $20^{\circ} \mathrm{C}$ was less than $50 \%$ producing a soft chocolate bar. Mixture of $10 \%-30 \%$ of fat blend consisting of 91\% PMF: 1\% PKO: 5\% POs IV 33: $3 \%$ POs IV 14 with CB improved the SFC at $20^{\circ} \mathrm{C}$ and produced SFC of $57 \%-72 \%$ with no eutecticity. Fat blend having 91\% PMF: 1\% PKO: 5\% POs IV
33: 3\% POs IV 14 with amount of 30\% and CB with amount of $70 \%$ was able to be demoulded by 30 min and produce snappability (breaking force) of $5032.71 \pm 85.91 \mathrm{~g}_{\mathrm{f}}$ at $20^{\circ} \mathrm{C}$ after one day stabilisation period.

\section{ACKNOWLEDGEMENT}

The authors would like to thank the DirectorGeneral of MPOB for his permission to publish the article. The authors would also like to thank Rozaini Shaukad Ali and the staffs of Food and Feed Technology Unit, for their assistance in ensuring the success of this project.

\section{REFERENCES}

AOCS (2012). Official Methods and Recommended Practices of the AOCS (Sixth edition). American Oil Chemists' Society.

Basso, R C; Ribeiro, A P B; Masuchi, M H; Gioielli, L A; Gonçalves, L A G; Santos, A O; Cardoso, L P and Grimaldi, R (2010). Tripalmitin and monoacylglycerols as modifiers in the crystallisation of palm oil. Food Chem., 122: 1185-1192.

Biswas, N; Cheow, Y L; Tan, C P and Siow, L F (2018). Physicochemical properties of enzymatically produced palm-oil-based cocoa butter substitutes (CBS) with cocoa butter mixture. Eur. J. Lipid Sci. Technol., 120: 1700205 (1-9). 
Biswas, N; Cheow, Y L; Tan, C P; Kanagaratnam, S and Siow, L F (2017). Cocoa butter substitute (CBS) produced from palm mid-fraction/palm kernel oil/ palm stearin for confectionery fillings. J. Am. Oil Chem. Soc., 94: 235-245.

Bolliger, S; Breitschuh, B; Stranzinger, M; Wagner, $\mathrm{T}$ and Windhab, E J (1998). Comparison of precrystallisation of chocolate. J. Food Eng., 35: 281297.

Bootello, M A; Chong, P S; Máñez, A; Garcés, R; Martínez-Force, E and Salas, J J (2018). Characterization of sunflower stearin-based confectionery fats in bulk and in compound coatings. J. Am. Oil Chem. Soc., 95: 1139-1150.

Bootello, M A; Hartel, R W; Garces, R; MatínezForce, E and Salas, J J (2012). Evaluation of high oleic-high stearic sunflower hard stearins for cocoa butter equicalent formulation. Food Chem., 134: 14091417.

Bootello, M A; Hartel, R W; Levin, M; MartinézBlanes, J; Real, C; Garces, R; Matínez-Force, E and Salas, J J (2013). Studies of isothermal crystallisation kinetics of sunflower hard-stearin-based confectionery fats. Food Chem., 139: 184-195.

Borhan, R H; Said, M and Mat Sahri, M (2011). Enzymatic interesterification of palm products for producing low calorie cocoa butter substitutes. J. Appl. Sci., 11: 3750-3754.

Braipson-Danthine, S and Gibon, V (2007). Comparative analysis of triacylglycerol composition, melting properties and polymorphic behavior of palm oil and fractions. Eur. J. Lipid Sci. Technol., 109: 359-372.

Cain, F W; Hughes, A D and Slanger, H (1995). Nonhydrogenated Coating Fats. US Patent, US5439700 A.

Calliauw, G; Foubert, I; De Greyt, W; Dijckmans, P; Kellens, M and Dewettinck, K (2005). Production of cocoa butter substitutes via two-stage static fractionation of palm kernel oil. J. Am. Oil Chem. Soc., 82: 783-789.

Chen, C; Zhang, H; Bi, Y and Cheong, L (2015). Effects of sucrose esters on isothermal crystallization of palm oil-based blend. J. Am. Oil Chem. Soc., 92: 277-286.

Çiftçi, O N; Fadiloğlu, S and Göğüş, F (2009). Conversion of olive pomace oil to cocoa butter-like fat in a packed-bed enzyme reactor. Biores. Technol., 100: 324-329.
Cleenewerck, B (2010). Low-trans for confectionery fat compositions. US Patent, US7700146 B2.

Compos, R and Marangoni, A G (2010). Molecular composition dynamics and structure of cocoa butter. Cryst. Growth Des., 10: 205-217.

De Clercq, N; Danthine, S; Nguyen, M T; Gibon, V and Dewettinck, K (2012). Enzymatic interesterification of palm oil and fractions: Monitoring the degree of interesterification using different methods. J. Am. Oil Chem. Soc., 89: 219-229.

De Graef, V; Vereecken, J; Smith, K W; Bhaggan, K and Dewettinck, K (2012). Effect of TAG composition on the solid fat content profile, microstructure and hardness of model fats with identical saturated fatty acid content. Eur. J. Lipid Sci. Technol., 114: 592-601.

Delbaere, C; Van, D; Depypere, F; Gellynck, X and Dewettinck, K (2016). Relationship between chocolate microstructure, oil migration and fat bloom in filled chocolates. Eur. J. Lipid Sci. Technol., 118: 1800-1826.

Elham, M; Nazanin, V and Ramli N (2013). Physicochemical properties and antioxidant activity of a synthetic cocoa butter equivalent obtained through modification of mango seed oil. Int. J. Food Sci. Technol., 48: 1549-1555.

Foubert, I; Dewettinck, K; Janssen, G and Vanrolleghem, P (2006). Modelling two-step isothermal fat crystallisation. J. Food Eng., 75: 551559.

Gibon, V (2011). Enzymatic interesterification of oils. Lipid Technol., 23: 274-277.

Gold, I L; Ukhun, M E and Akoh, C C (2011). Characteristics of eutectic compositions of restructured palm oil olein, palm kernel oil and their mixtures. J. Am. Oil Chem. Soc., 88: 1659-1667.

Himawan, C; Starov, V M and Stapley, A G F (2006). Thermodynamic and kinetic aspects of fat crystallization. Adv. Colloid Interface Sci., 122: 3-33.

Jahurul, M H A; Zaidul, I S M; Nik Norulaini, N A; Sahena, F; Jinap, S; Azmir, J; Syarif, K M and Mohd Omar, A K (2013). Cocoa butter fats and possibilities of substitution in food products concerning cocoa varieties, alternative sources, extraction methods, composition, and characteristics. J. Food Eng., 117: 467-476.

Jahurul, M H A; Zaidul, I S M; Nik Norulaini, N A; Sahena, F; Abedin, M Z; Kashif, Ghafoor and Mohd Omar, A K (2014a). Characterization of 
crystallization and melting profiles of blends of mango seed fat and palm oil mid-fraction as CBR using differential scanning calorimetry and pulse nuclear magnetic resonance. Food Res. Int., 55: 103109.

Jahurul, M H A; Zaidul, I S M; Nik Norulaini, N A; Sahena, F; Abedin, M Z; Mohamed, A and Mohd Omar, A K (2014b). Hard cocoa butter replacers from mango seed fat and palm stearin. Food Chem., 154: 323-329.

Jeyarani, T and Reddy, S Y (1999). Heat-resistant cocoa butter extenders from mahua (Madhuca latifolia) and kokum (Garcinia indica) fats. J. Am. Oil Chem. Soc., 76: 1431-1436.

Jorge, M C; Rodriguez, I and Hombre, R (1999). Evaluation of an instrumental method of texture analysis for quality control of chocolate bars. Alimentaria, 36: 73-76.

Jun, J; Pembe, W; Ce, Q; Cong, S; Liang, J; Dan, X; Jianhua, H; Qingzhe, J and Xingguo, W (2016). Mango kernel fat based chocolate with heat resistant triacylglycerols: Production via blending using mango kernel fat mid-fraction and palm midfractions produced in different fractionation paths. RSC Adv., 110: 108981-108988.

Kadivar, S; De Clercq, N; Mokbul, M and Dewettinck, K (2016). Influence of enzymatically produced sunflower oil based cocoa butter equivalents on the phase behavior of cocoa butter and quality of dark chocolate. LWT - Food Sci. Technol., 66: 48-55.

Kang, K K; Jeon, H; Kim, I-H and Kim, B H (2013). Cocoa butter equivalents prepared by blending fractionated palm stearin and shea stearin. J. Food Sci. Biotechnol., 22: 347-352.

Kang, K K; Kim, S; Kim, I H; Lee, I H and Kim, B H (2003). Selective enrichment of symmetric monounsaturated triacylglycerols from palm stearin by double solvent fractionation. J. Food Sci. Technol., 51: 242-252.

Keijbets, E L; Chen, J and Vieira, J (2010). Chocolate demoulding and effects of processing conditions. J. Food Eng., 98: 133-140.

Larsen, M K; Andersen, K K; Kaufmann, N and Wiking, L (2014). Seasonal variation in the composition and melting behaviour of milk fat. J. Dairy Sci., 97: 4703-4712.

Marangoni, A (2002). Special issue of FRIcrystallization, structure and functionality of fats. Food Res. Int., 35: 907-908.
Marangoni, A G and McGauley S E (2003). Relationship between crystallization behaviour and structure in cocoa butter. Crys. Growth Des., 3: 95-108.

Metin, S and Hartel, R W (2005). Crystallization of fats and oils. Part 1: Edible Oil and Fat Products: Chemistry, Properties and Health Effects. Bailey's Industrial Oil and Fat Products. John Wiley \& Sons, Inc. p. 45-73.

Mohamed, I O (2013). Lipase-catalysed acidolysis of palm mid fraction oil with palmitic and stearic fatty acid mixture for production of cocoa butter equivalent. Appl. Biochem. Biotechnol., 171: 655-666.

MPOB (2005). Methods of test for palm oil and palm oil products. MPOB Test Method. MPOB, Bangi.

MPOC (2006). Palm-based chocolate products. Palm Oil and Palm Kernel Oil Applications. p. 37-42.

Mutia, R; Abang Zaidel, D N and Muhamad, I I (2016). Optimisation of cocoa butter equivalent production from formulated hard palm oil midfraction and canola oil fats. J. Teknol. (Sci. Eng.), 78: 127-134.

Narine, S S and Marangoni, A G (1999). Relating structure of fat crystal networks to mechanical properties: A review. Food Res. Int., 32: 227-248.

Nik Norulaini, N A; Zaidul, I S M; Anuara, O and Mohd Omara, A K (2004). Supercritical enhancement for separation of lauric acid and oleic acid in palm kernel oil (PKO). Sep. Purif. Technol., 39: 133-138.

Norazura Aila, M H and Noor Lida, H M D (2017). Usage of palm oil, palm kernel oil and their fractions as confectionery fats. J. Oil Palm Res., 29: 301-310.

Norizzah, A R; Chong, C L; Cheow, C S and Zaliha, $\mathrm{O}$ (2004). Effects of chemical interesterification on physiochemical properties of palm stearin and palm kernel olein fats. Food Chem., 86: 229-235.

Nusantoro, B P (2009). Physicochemical properties of palm stearin and palm mid fraction obtained by dry fractionation. Agritech., 29: 154-158.

Oleivera, G M; Ribeiro, A P B; Santos, A O; Cardoso, L P and Kieckbusch, L A G (2015). Hard fats as additives in palm oil and its relationships to crystallisation process and polymorphism. Food Chem., 122: 1185-1192.

Peyronel, F; Campos, R and Marangoni, A G (2016). Prevention of oil migration in palm mid fraction and palm olein using a stabilizer rich in behenic acid. Food Res. Int., 88: 52-60. 
Quast, L B; Luccas and Kieckbusch, T G (2011). Physical properties of pre-crystallized mixtures of cocoa butter and cupuassu fat. Grasas Aceites, 62: 6267.

Quast, L B; Luccas, V; Ribeiro, A P; Cardosa, A P and Kieckbusch, T G (2013). Physical properties of tempered mixtures of cocoa butter, CBR and CBS fats. Int. J. Food Sci. Technol., 48: 1579-1588.

Rios, R V; Pessanha, M D F; de Almeida, P F; Viana, C L and Lannes, S C S (2014). Application of fats in some food products. Food Sci. Technol. (Campinas), 34: 3-15.

Rowat, A C; Hollar, K A; Stone, H A and Rosenberg, D (2011). The science of chocolate: Interactive activities on phase transitions, emulsification and nucleation. J. Chem. Edu., 88: 29-33.

Sakamotoa, M; Ohbab, A; Kuriyamaa, J; Maruoa, K; Uenob, S and Sato, K (2004). Influences of fatty acid moiety and esterification of polyglycerol fatty acid esters on the crystallisation of palm mid fraction in oil-in-water emulsion. Colloid Surf. B., 37: 27-33.

Sato, K (2001a). Crystallization behaviour of fats and lipids - A review. Chem. Eng. Sci., 56: 2255-2265.

Sato, K (2001b). Molecular Aspects in Fat Polymorphism. AOCS Press, Champaign. p. 1-15.

Smith, K W (2009). Crystallisation and physical properties of fats. Eur. J. Lipid Sci. Technol., 111: 217218.

Soekopitojo, S (2011). Enzymatic interesterification of palm oil based starting materials for the production of cocoa butter equivalents. Central Library of Bogor Agricultural Library. http:// repository.ipb.ac.id/handle/123456789/51718.

Soekopitojo, S; Hariyadi, P and Andarwulan, N (2009). Enzymatic interesterification of palm oil midfraction fats for the production of cocoa butter equivalents. As. J. Food Ag-Ind., 2: 807-816.

Sonwai, S; Kaphueakngam, P and Flood, A (2014). Blending of mango kernel fat and palm oil midfraction to obtain cocoa butter equivalent. J. Food Sci. Technol., 51: 2357-2369.

Stroppa, V L Z; Ribeiro, A P B; Luccas, V; Grimaldi, R; Gonçalves, L A G and Kieckbusch, T G (2014). Influence of soy protein and PGPR levels in chocolate crystallisation behaviour. International Congress on Engineering and Food. http:/ / www.icef11.org/ content/papers/epf/EPF1081.pdf., accessed on 7 July 2020.
Talbot, G (2009). Fats for Confectionery Coatings and Fillings. Woodhead Publishing Series in Food Science, Technology and Nutrition. p. 53-79.

Timms, R E (2003). Properties, Production and Application. Confectionery Fats Handbook, The Oily Press. p. 229-325.

Toro-Vazquez, J F; Pérez-Martínez, D; DibildoxAlvarado, E; Charó-Alonso, $\mathrm{M}$ and ReyesHernández, J (2004). Rheometry and polymorphism of cocoa butter during crystallization under static and stirring conditions. J. Am. Oil Chem. Soc., 81: 195-202.

Vereecken, J; Foubert, I; Smith, KW and Dewettinck, K (2009). Effect of SatSatSat and SatOSat on crystallization of model fat blends. Eur. J. Lipid Sci. Technol., 111: 243-258.

Wainwright, R E (1996). Oils and fats in confections. Bailey's Industrial Oil and Fat Products (Fifth edition), Vol. 3. John Wiley and Sons Inc., New York, USA. p. 353-407.

Wu, H-C and Deng, J (2005). Cocoa butter equivalent produced by enzymatic interesterification of palm oil mid fraction in solvent free system through orthogogal tests. Sichuan Food and Fermentation 2005-2004. http://en.cnki.com.cn/Article_en/ CJFDTOTAL-SKSF200504007.htm.

Zaidul, I S M; Nik Norulaini, N A; Mohd Omar, A K and Smith Jr, R L (2006). Supercritical carbon dioxide $\left(\mathrm{SC}-\mathrm{CO}_{2}\right)$ extraction and fractionation of palm kernel oil from palm kernel as cocoa butter replacers fat. J. Food Eng., 73: 210-216.

Zaidul, S M; Nik Norulaini, N A; Mohd Omar, A K and Smith Jr, R L (2007). Blending of supercritical carbon dioxide $\left(\mathrm{SC}-\mathrm{CO}_{2}\right)$ extracted palm kernel oil fractions and palm oil to obtain cocoa butter replacers. J. Food Eng., 78: 1397-1409.

Zhou, S-L; Zhang, F-Q; Jin, Q-Z; Liu, Y-F; Shan, L; Zhang, T; Zou, X-Q and Wang, X-G (2010). Characterization of palm kernel oil, palm stearin and palm olein blends in isosolids diagrams. Eur. J. Lipid Sci. Technol., 112: 10411047.

Żyżelewics, D; Budryn, G; Krysiak, W; Oracz, J; Nebesny, E and Bojczuk, M (2014). Influence of roasting conditions on fatty acid composition and oxidative changes of cocoa butter extracted from cocoa bean of Forastero variety cultivated in Togo. Food Res. Int., 63: 328-343. 